\title{
Research Paper \\ Effectiveness of Hydrotherapy on Communication Skills of Children with Autism Spectrum Disorder: A Single Case Study
}

\section{Samad Azimigarosi* ${ }^{* 1}$, Aliakbar Arjmandnia ${ }^{2}$, Alireza Mohseni Ezhei ${ }^{3}$, Mostafa Asgari $^{4}$}

1. Ph.D. Student of Psychology of Exceptional Children, Faculty of Psychology and Educational Sciences, University of Tehran, Iran

2. Associate Professor, Department of Exceptional Children, Faculty of Psychology and Educational Sciences, University of Tehran, Iran

3. Ph.D. Student of Psychology of Exceptional Children, Faculty of Psychology and Educational Sciences, University of Isfahan, Iran 4. M.A. in Clinical Child and Adolescent Psychology, Faculty of Psychology and Educational Sciences, University of Tabriz, Iran

Citation: Azimigarosi S, Arjmandnia A, Mohseni Ezhei A, Asgari M. Effectiveness of hydrotherapy on communication skills of children with autism spectrum disorder: a single case study. Quarterly Journal of Child Mental Health. 2020; 6(4): 35-50.

http://dx.doi.org/10.29252/jcmh.6.4.5

\section{A R T I C L E I N F O}

\section{Keywords:}

Hydrotherapy,

communication skill, autism spectrum disorder

Received: 12 May 2019

Accepted: 27 Aug 2019

Available: 1 Mar 2020

\section{A B S T R A C T}

Background and Purpose: Autism spectrum disorder (ASD) affects communication skills and appropriate response to the outside environment. One of the newest ways to improve the communication skills of children with autism spectrum disorder is hydrotherapy. The purpose of this study was to investigate the effect of hydrotherapy on communication skills of children with ASD.

Method: This study is a single case study with A-B design. The statistical population includes all children with ASD in Alborz province in 2017. Purposeful sampling was used to select the sample. Accordingly, 3 children with autism disorder symptoms and symptoms were selected from Kahrizak rehabilitation center as a sample. The research instrument was the second version of the Gilliam Autism Rating Scale (GARS-2) and a researcher-made checklist for measuring communication skills. According to the Hollywick program, treatment sessions were conducted in 2 sessions (one hour) per week and for 2 months during 8 weeks (16 sessions).

Results: During the visual analysis of chart, intervention was effective in all three subjects. The percentage of non-overlapping data (PND) in the two baseline and intervention situations for the 3 subjects were $100 \%, 80 \%$, and $90 \%$.

Conclusion: The results showed that hydrotherapy significantly increased the communication skills of children with ASD, which could be achieved by enhancing sensory motor skills as well as providing the necessary contexts and conditions for communication. Therefore, it is recommended to use this method as a complementary approach in the field of education and rehabilitation of children with ASD along with other therapies.

\footnotetext{
* Corresponding author: Samad Azimigarosi, Ph.D. Student of Psychology of Exceptional Children, Faculty of Psychology and Educational Sciences, University of Tehran, Iran.

E-mail addresses: Smd.azimi@gmail.com
}

2476-5740/ () 2019 The Authors. This is an open access article under the CC BY-NC-ND license (https://creativecommons.org/licenses/by-nc-nd/3.0/). 


\section{اثربخشى آبدرمانى بر مهارتهاى ارتباطى كود كان مبتلا به اختلال طيف اوتيسم (مطالعه تكبررسى) \\ صمد عظيمى گروسى"'، على اكبر ارجمندنيا'، عليرضا محسنى ازيه"، مصطفى عسكرى

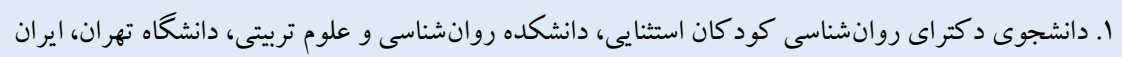

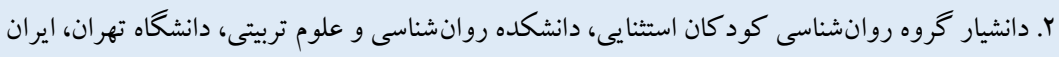

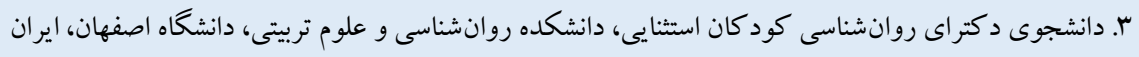

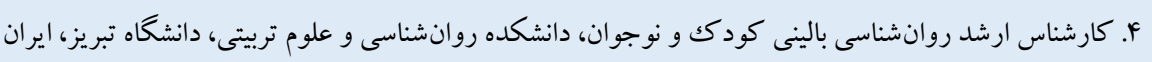

جكيده

زمينه و هدف: اختلال طيف اوتيسم، مهارت هاى ارتباطى و ياسخ مناسب فرد به محيط بيرون را تحت تأثير قرار مىدهد. يكى از جديدترين

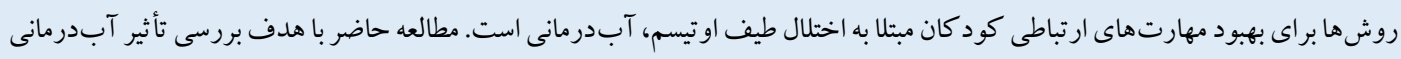
بر مهارتهاى ارتباطى كود كان داراى اختلال طيف اوتيسم انجام شد.

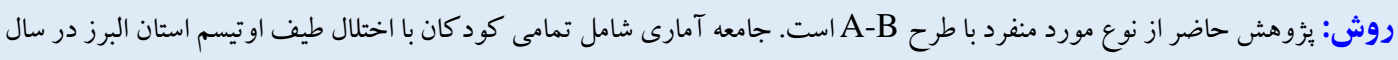

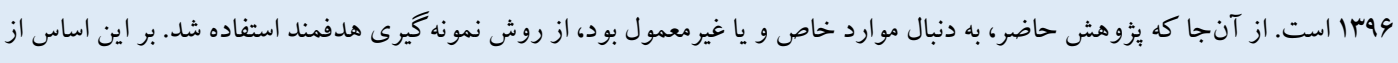

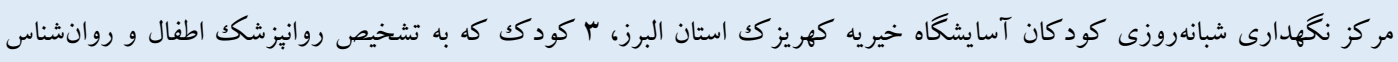

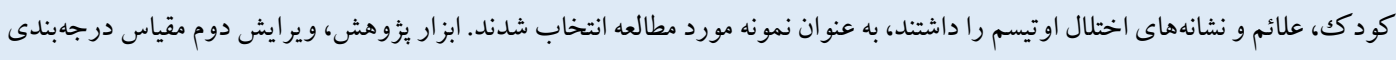

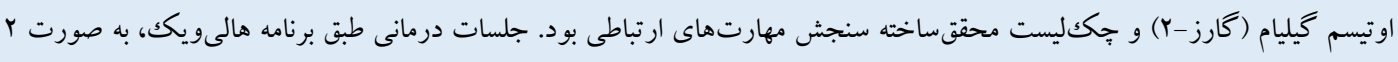

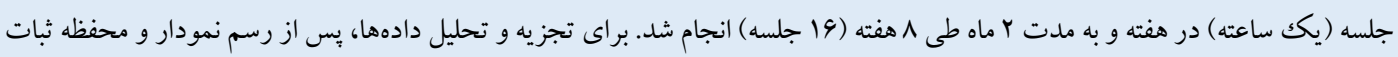

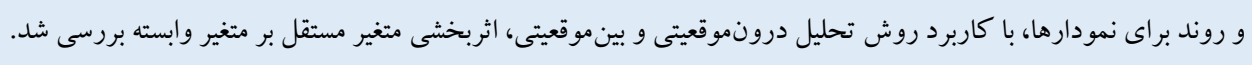

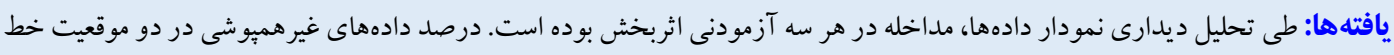

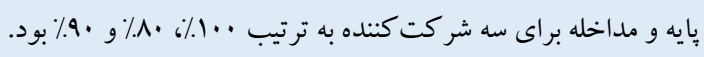

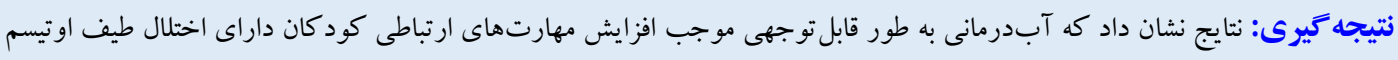

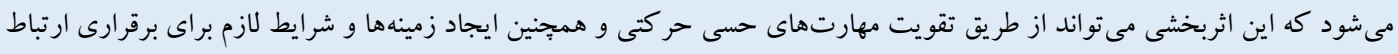

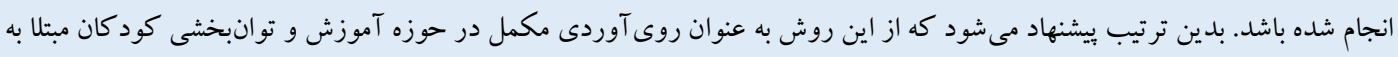
اختلال طيف او تيسم در كنار ساير درمانهاى اصلى استفاده شود.
مشخصات مقاله

كليدوازهها:

آبدرمانى، كليدوان

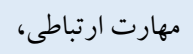

اختلال طيف اوتيسم
دريافت شده:

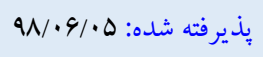
منتشر شده:

* نويسنده مسئول: صمد عظيمى گروسى، دانشجوى دكتراى روانشناسى كود كان استنايى، دانشكده روانشناسى و علوم تربيتى، دانشكاه تهران، ايران.

رايانامه: Smd.azimi@gmail.com

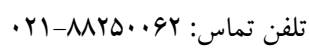


هييو تالاموس سـاخته مى شود. اين هورمون در بيشتر نورونهاى ارسالى به مقلدمه

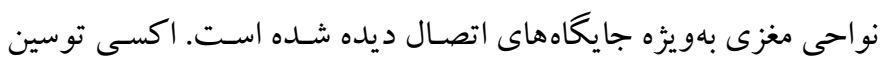

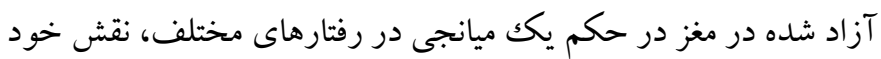

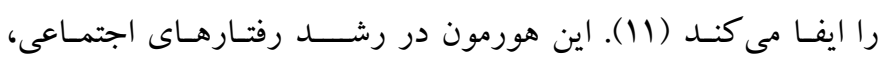

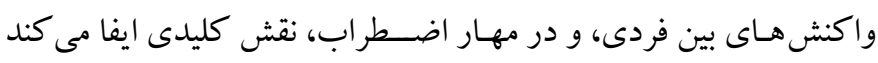

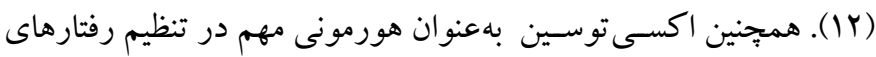

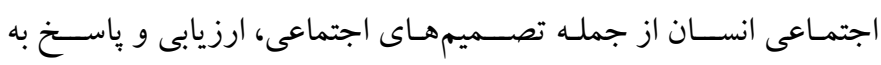

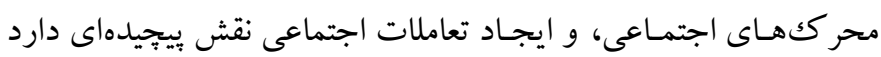

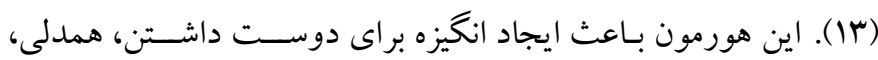

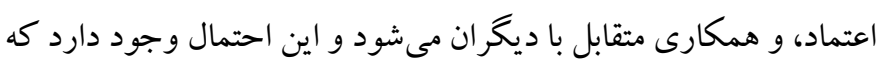

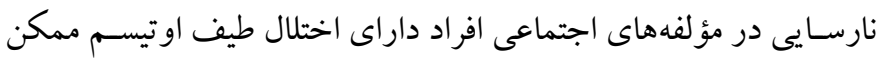

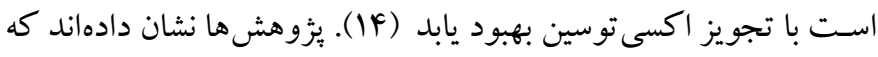

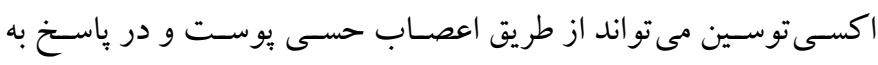

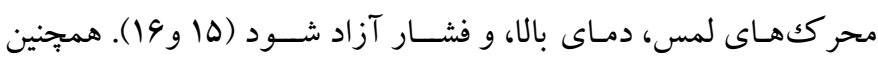

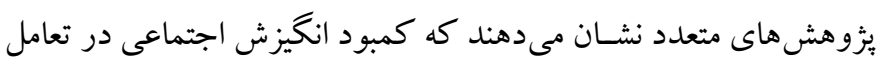

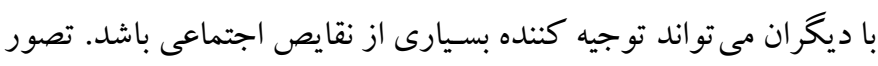

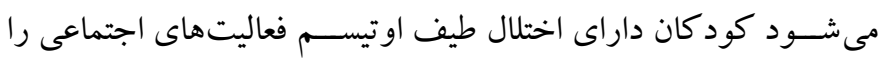

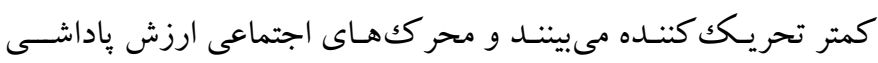

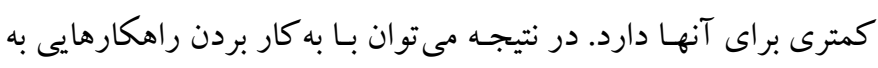

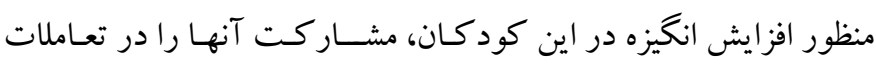

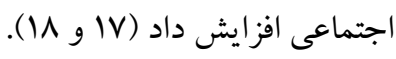
با توجه به بيامدهاى منفى نارسـايى در مهارت هاى ارتباطى كود كان

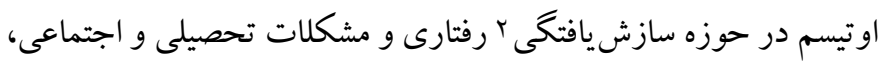
مداخلات بسـيارى در اين زمينه طراحى شـدهاند كه با وجود اينكه امكان درمان قطعى كامل براى اين اختلال وجود ندارد، اما قابليت بهبود نسبى به به به به

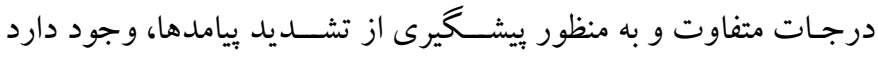
(19). طبق بررسـى هاى انجام شــهه هيج درمان واحدى براى اين اختلال

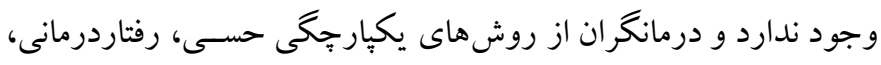
موسـيقىدرمانى، كاردرمانى، گفتتاردرمانى، دارودرمانى، و يا تر كيبى از از

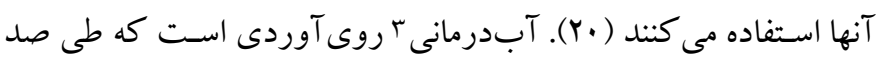

اختلال طيف اوتيسم ' يكى از اختلالات عصبى - تحولى بيجيده است كه

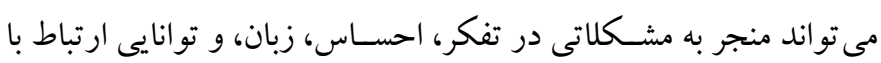

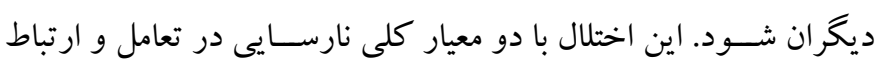

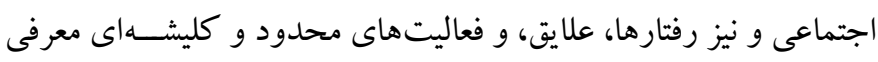

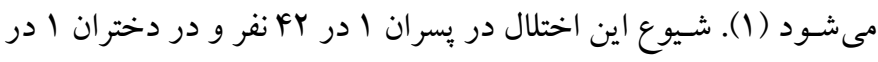

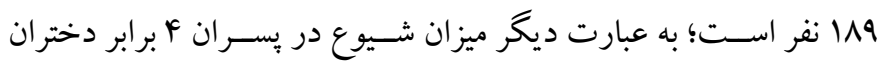

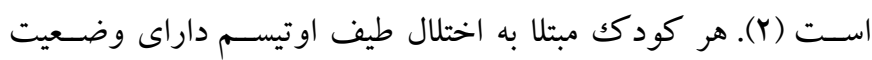

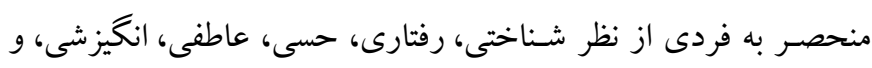

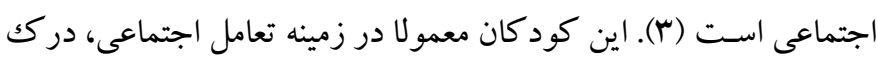

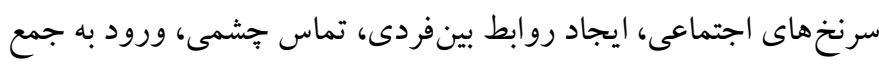

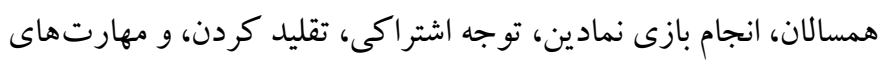

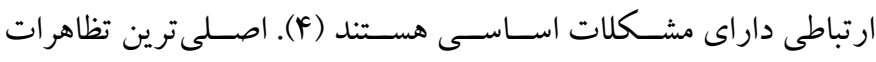
مشــكلات كود كان اوتيســـم در مهارتهاى ارتباطى در زمينههايى مانند ارتباط جشـمى ضعيف، فقدان احساسات يا تبادلات اجتماعى، استفاده از

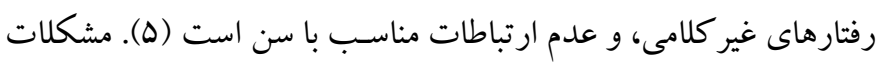

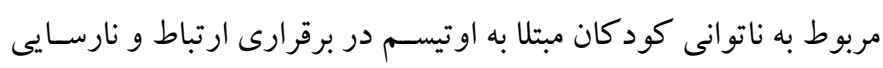

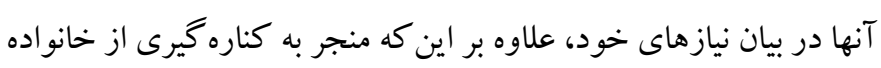
و اجتماع مى شـود، همجنين موجب عدم موفقيت در فعاليت هاى شغلى و

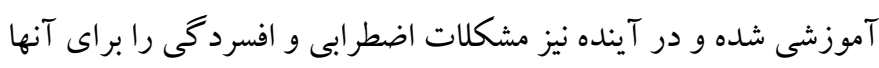

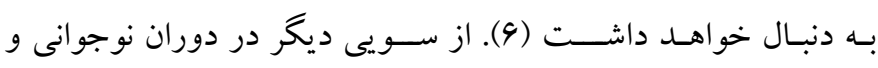

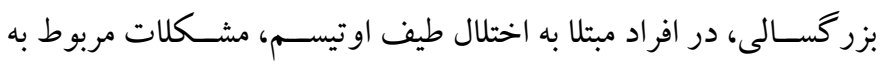

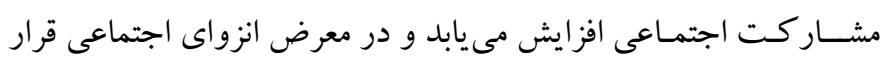

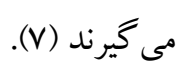
يكى از عواملى كـه بـا مشــكلـات ارتباطى افر اد داراى اختلال طيف

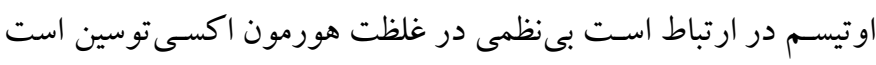

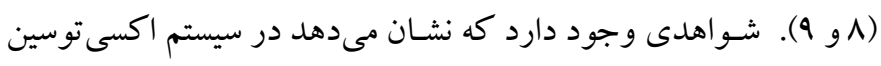
افر اد داراى اختلال طيف اوتيسم نابهنجارى وجود دارد و اين هورمون در رفتارهاى كليشهاى و رفتارهاى اجتماعى نقش دارد ( •.). اكسى توسين

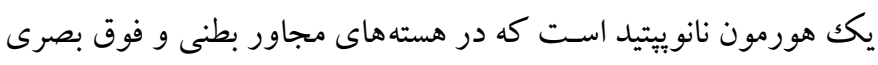


بـه بررسـى تأثير تمرينات آبدرمانى بر عادات خواب ^ كود كك داراى

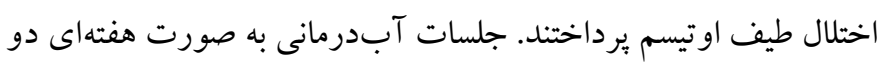

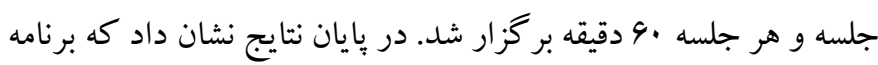

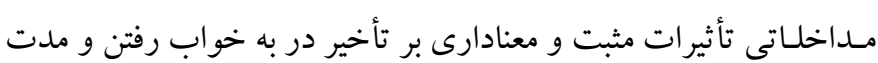

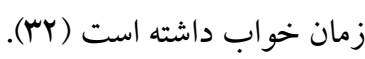

در بررسى تأثير روش آبدرمانى مشـخص شد كه اين شيوه روشى

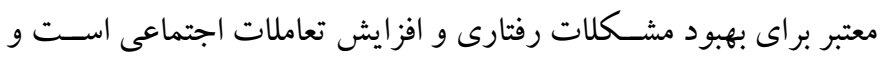
مى توان آن را بـه عنوان روشـى ايمن و مؤثر در كود كـان داراى اختلال

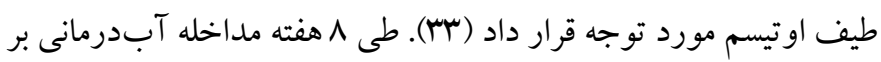

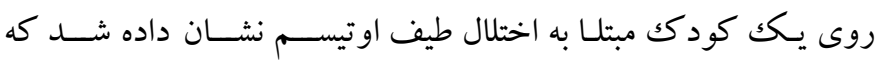

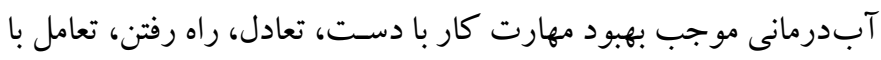

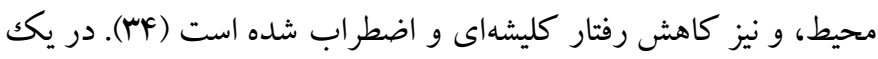

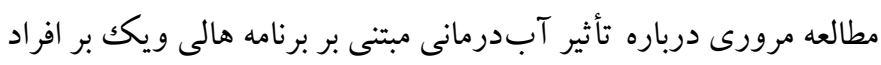
داراى اختلال طيف اوتيسم مشخص شد كه اين شيوه موجب بهبود تعامل

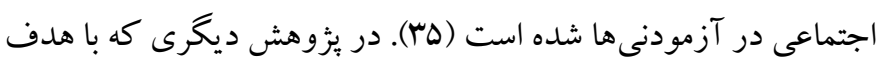

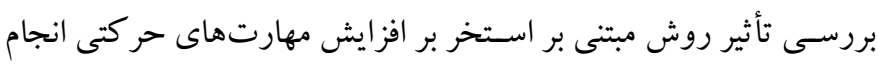

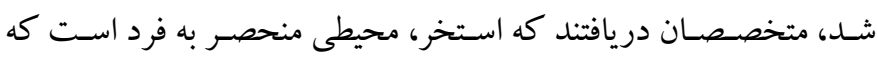
مى تو اند موجب بهبود مهارت هاى حر كتى اجتماعى شـود (4). همجِنين

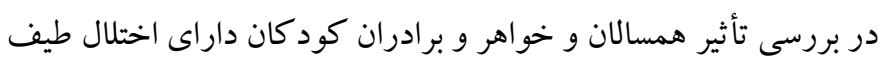

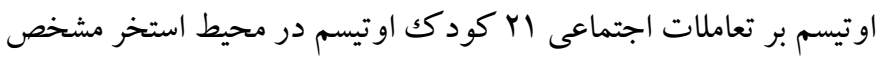

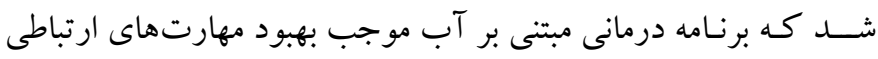

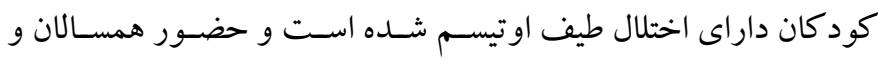

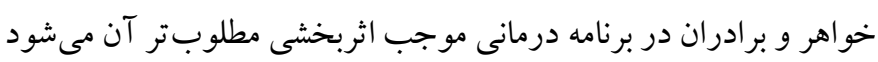

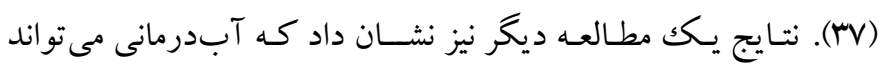
موجب افزايش توجه، بهبود قدرت عضلانى، تعادل، تعديل حسى، ايجاد و حفظ تماس جشمىى، و مشاركت اجتماعى شود (rᄉ). محيط آب محيط منحصـر بـه فردى اســت كه انبوهى از محر كات مطلوب را براى حواس بينايى، لامسـه و حر كت ايجاد مى كند كه سـاير

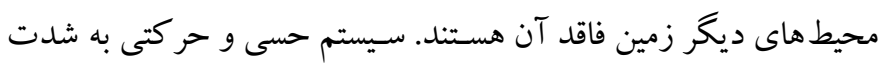

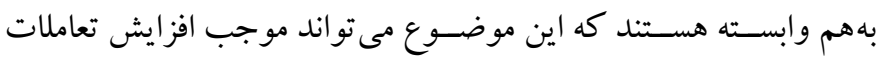

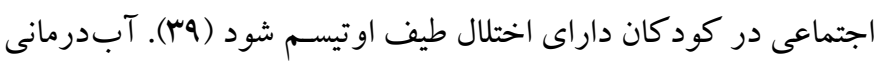

سـال اخير براى درمان افراد با نيازهاى ويزٔه مورد توجه قرار گرفته اسـت

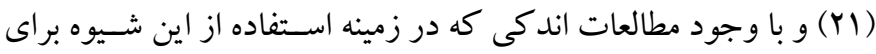

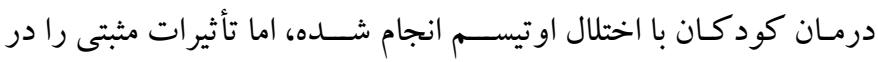
مهارت هاى ارتباطى، حر كتى و بهبود وضـعيت رفتارى آنها نشـان داده

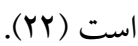
آبدرمانى به معنى اسـتفاده از آب در هر يكك از اشـكال آن (آب، يخ، بخار) با درجه حرارتهاى مختلف، طول مدت و و فشارهاى متفاوت،

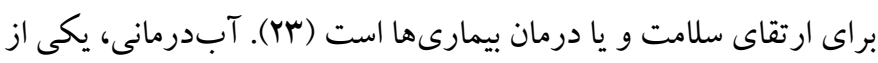

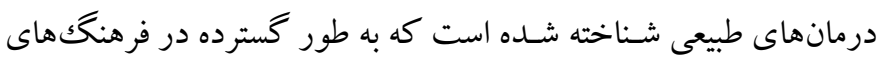

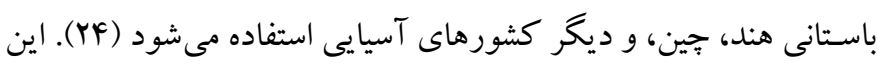
روش براسـاس اصول شناور بودن، فشار هيدرواستاتيك،، تلاطم، و جريان

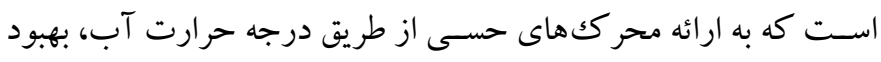

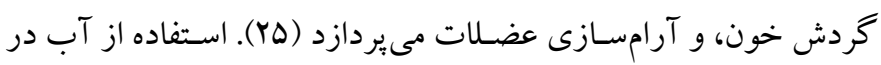

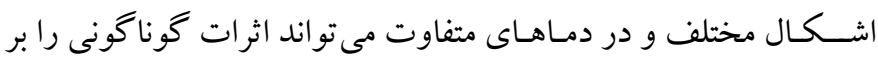

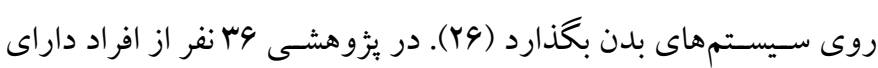

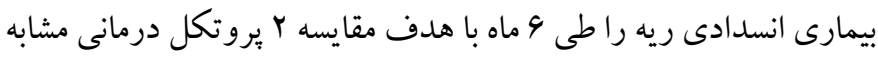
كه در محيط آب و زمين اجرا مىشــ، مورد بررسى قرار دادند. در بايان

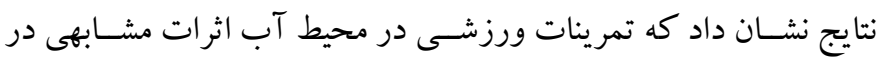

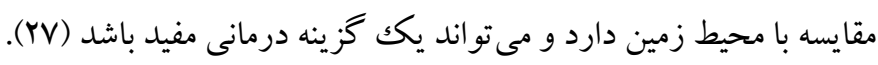

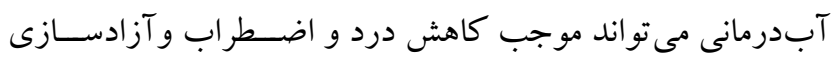

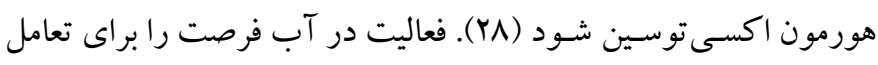

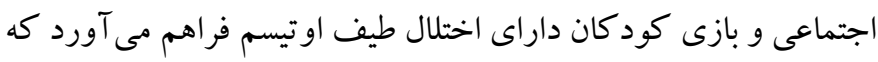

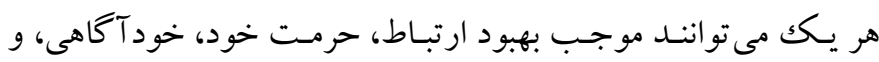

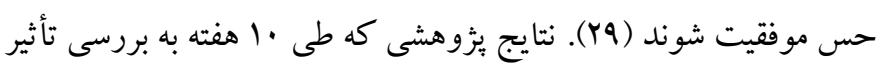

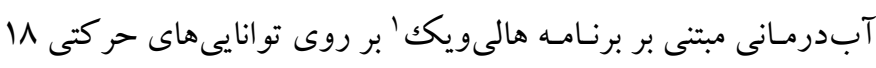

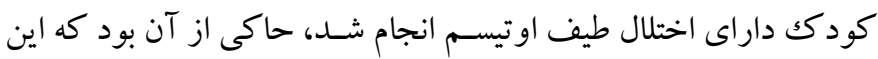

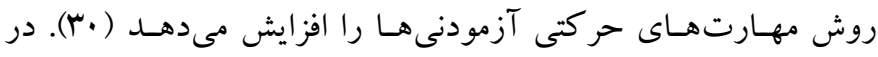

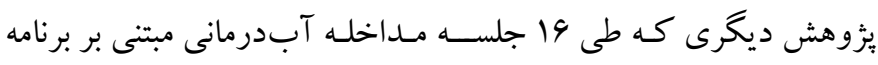
هالىويك بر روى سه كودك داراى اختلال طيف اوتيسم انجام گرديد،

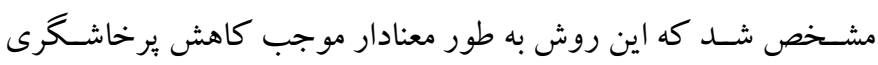

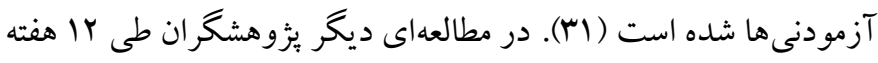

1. Halliwick 
خروج توسط يكى از متخصصان كود كان با نيازهاى خاص مورد ارزيابى في في

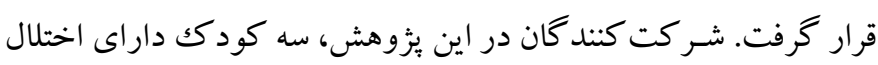

$$
\text { طيف اوتيسم بودند كه ويثزى هاى آنها به شرح زير است: }
$$

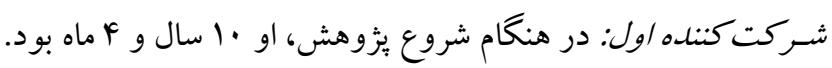

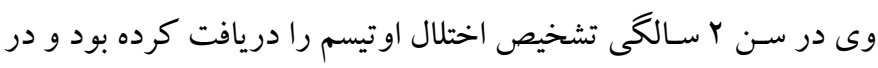

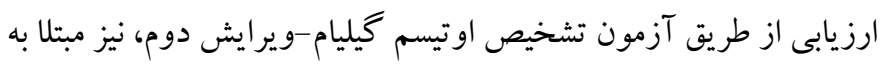

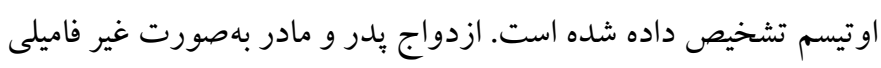

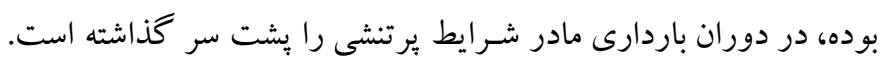

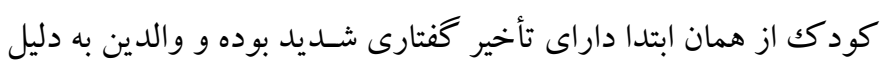
مناسـب نبودن وضسعيت مالى درمانهاى توانبخشـى را انجام ندادند. در

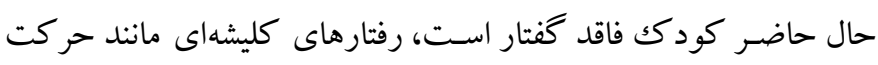

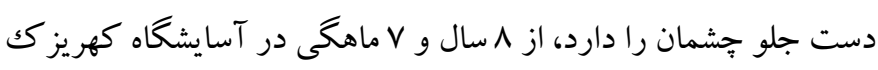

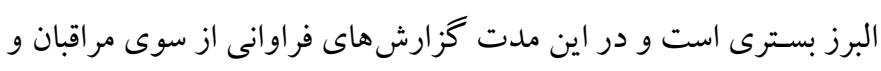

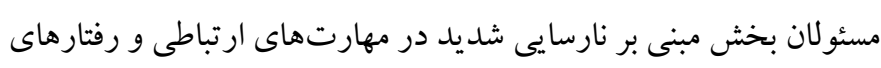

$$
\text { خود آسيبى ارائه شده است. }
$$

شركت كننده دوم: در هنگام شروع ئزوهش، او · ل سال و 9 ماه بود.

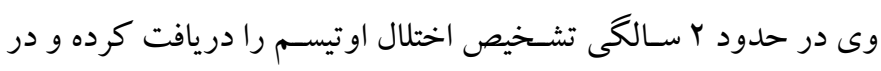

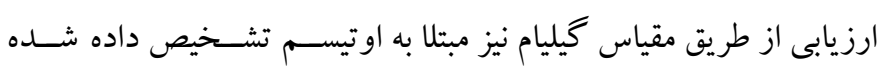

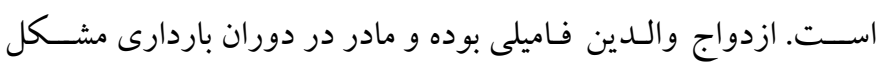
خاصى نداشته است. زايمان به صورت طبيعى بوده و كودكك نيز در زمان

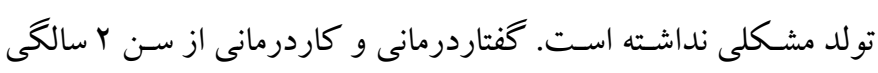
آغاز شـده و اكنون نيز در حال انجام اسـت. كود كك داراى كلام بسـيار

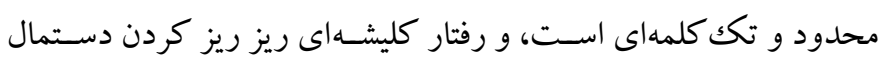

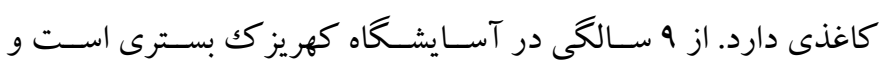

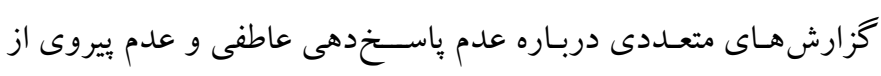

$$
\text { دستورات از سوى مراقبان ارائه شده است. }
$$

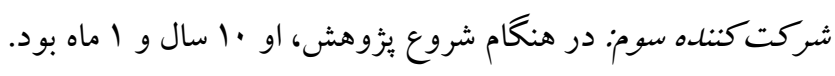

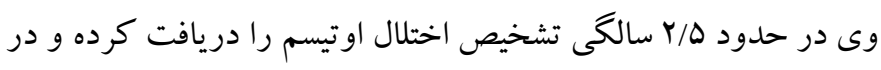

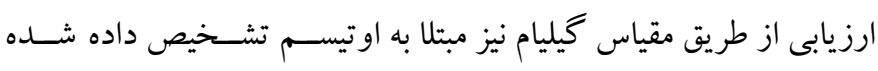

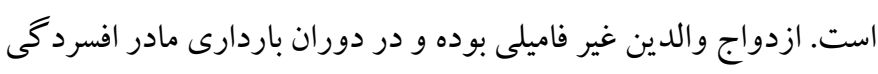

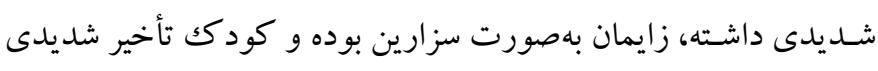

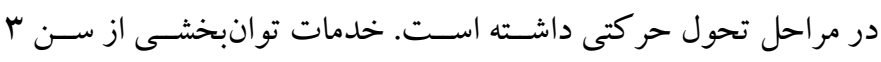

در فعالسـازى سـيستم حسىى، هيجانى، و حر كتى نقش دارد و مىتواند

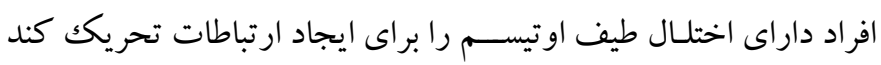

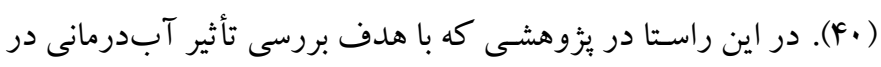

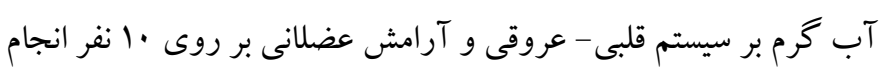

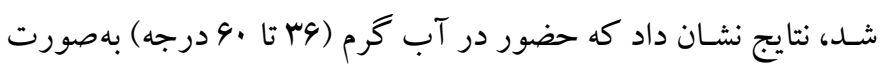

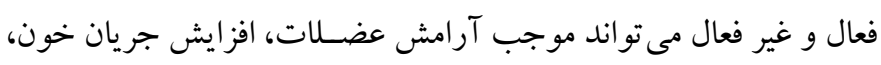

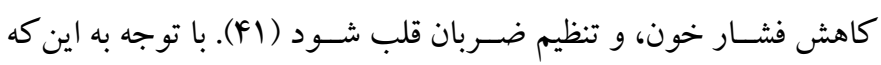

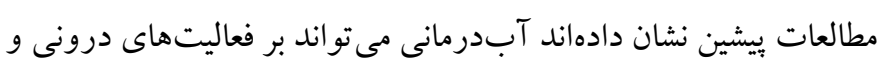

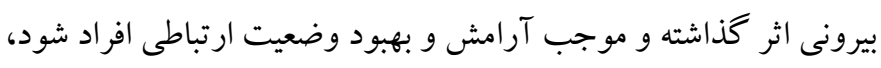

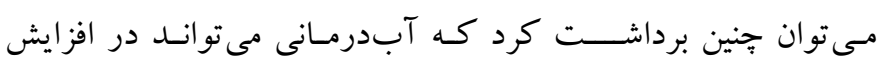

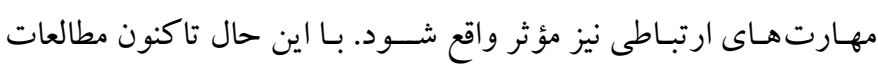

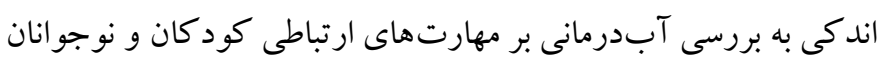

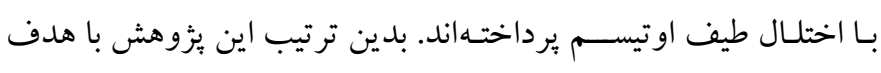

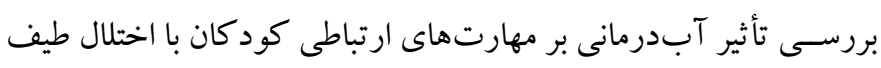

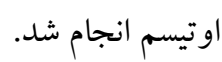

روش

الف) طرح هزوهش و شــر كت كنند كان: يزوهش حاضـر از نوع مورد

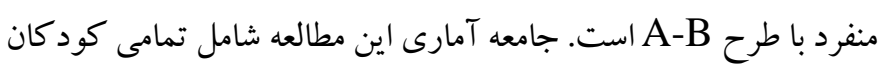

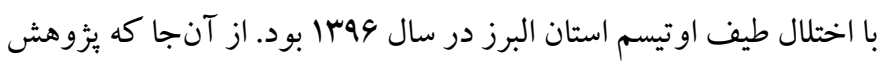

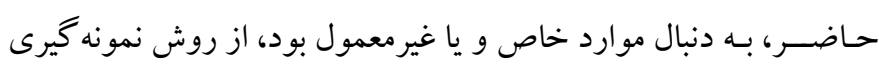

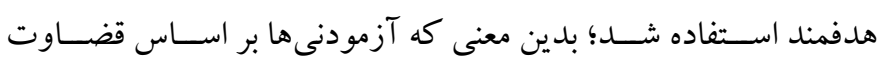

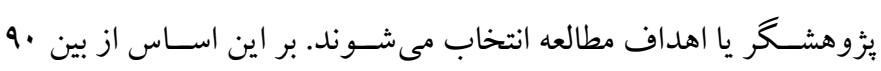
كودك بسترى در مركز نخهدارى شبانهروزى كود كان آسايشگاه خيريه

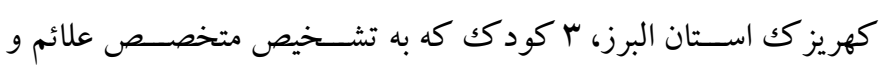

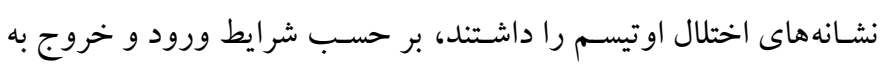

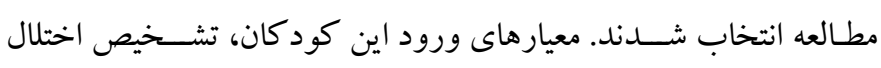

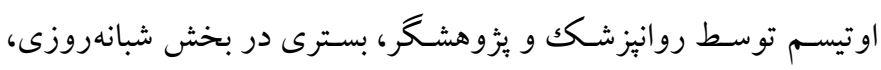

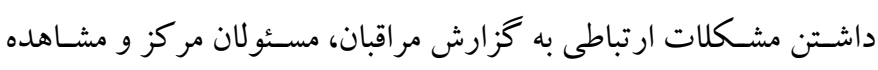

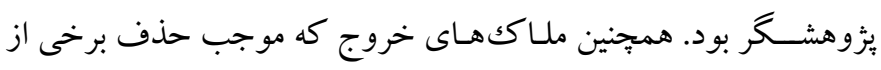

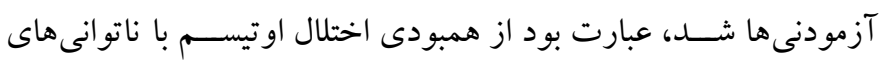

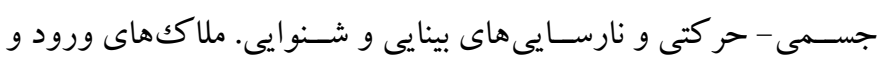




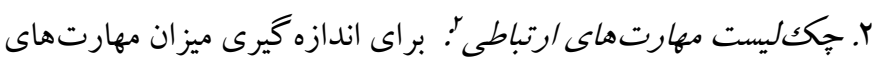

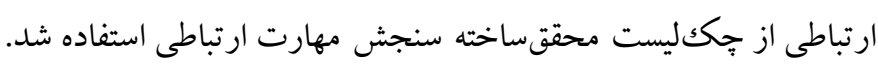

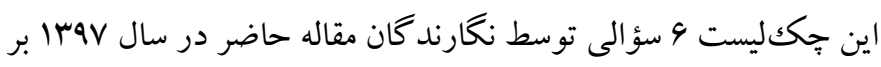

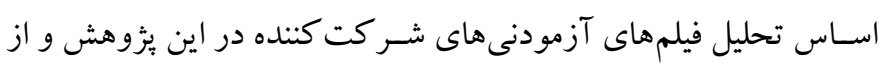

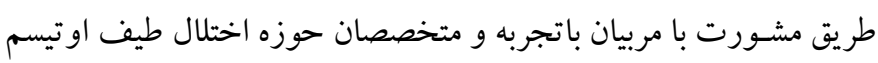

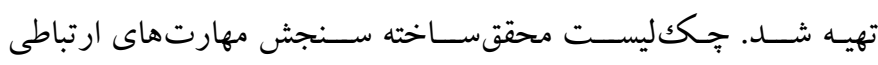

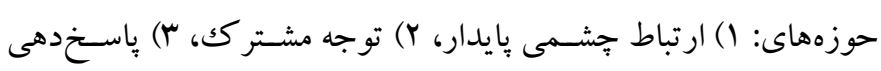
عاطفى مناسب، F) درخواست كردن، ه) پاسخد هـى مناسب به دستورات،

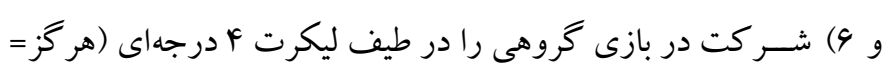

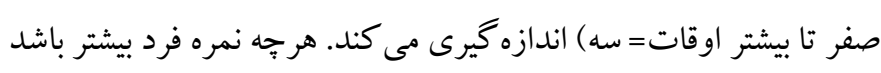

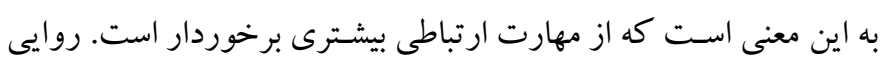
محتو ايى اين جكك ليست توسط متخصصان روانشناسى كود كان استثنايى

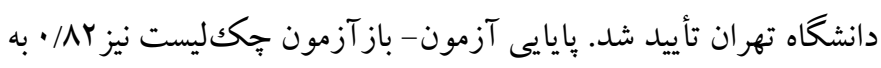

دست Tسمد.

ج) برنـامه مداخلهاى: جلســات درمانى اين يزوهش بركرفته از برنامه

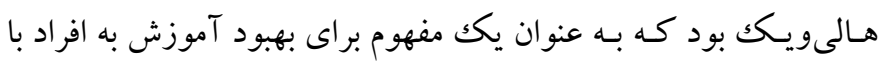

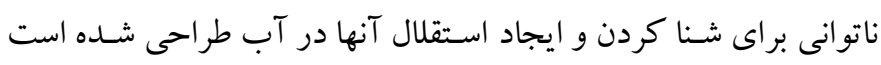

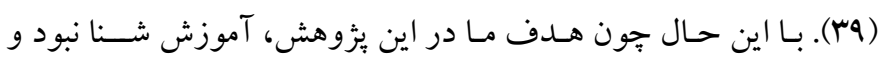
افز ايش مهارت هاى ارتباطى هدف اصسلى بود، سـعى شـد با اسـتفاده از

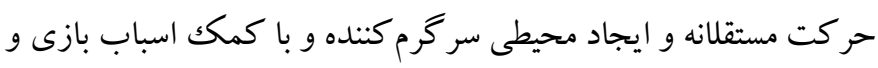

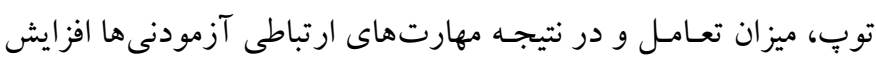

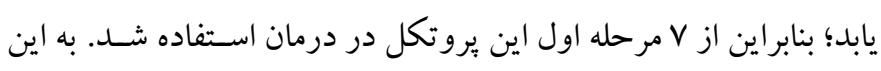

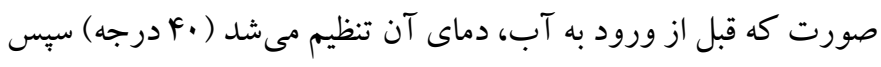

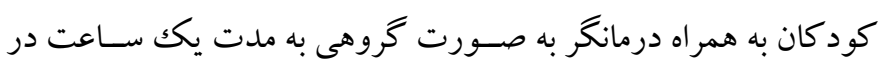

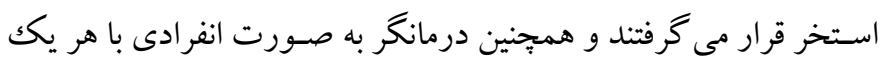

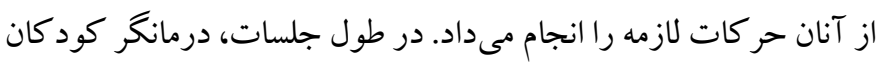

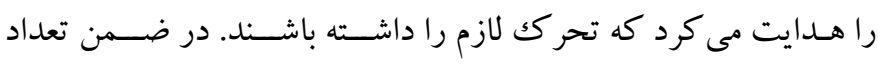

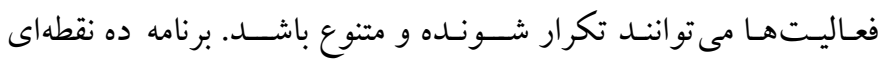

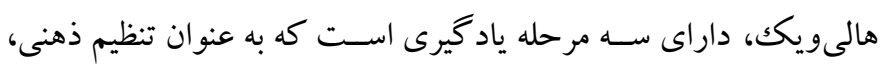

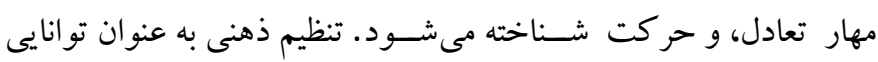

سالكى آغاز و تا 9 سالكى ادامه داشت كه به دليل عدم ييشرفت كودك،

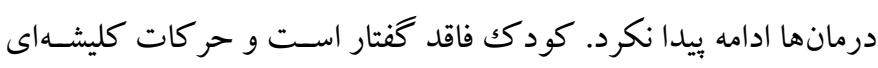

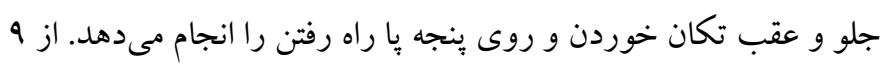

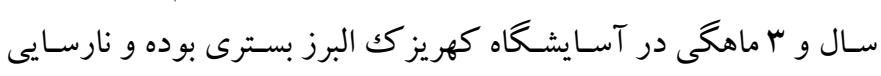
شديد در ارتباط جشمى و مهارت هاى ارتباطى دارد. ب) ( ب ابزار ا. آزمون تشـخيص اوتيسـم كيليام-ويرايش دوم': اين آزمون در سـال

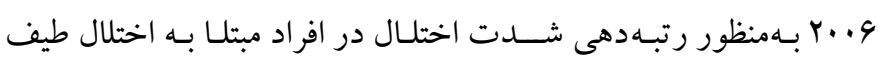

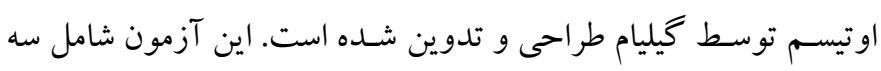

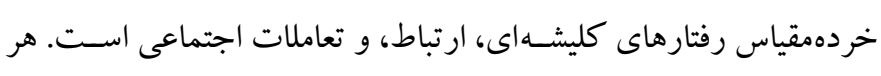

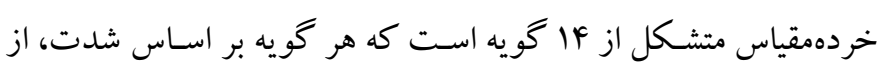

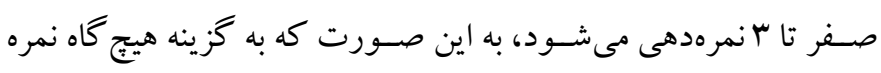

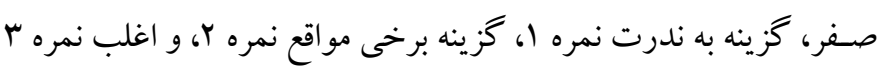

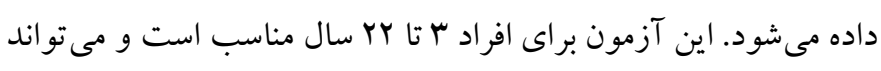

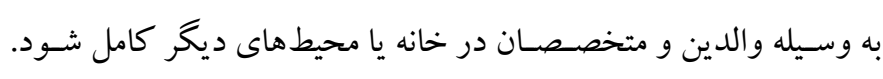
نمرات هر خرده مقيـاس بـا يكـديخر جمع و به نمرات اسـتاندارد تبديل

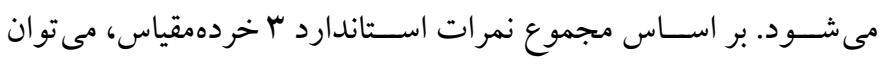

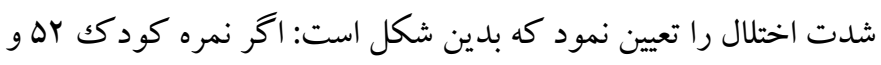

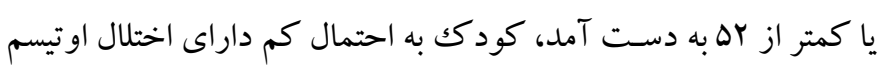

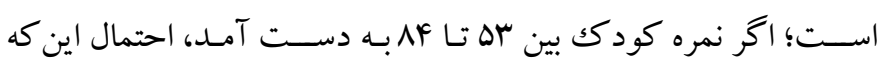
كود كك داراى اختلال اوتيسم باشد، متوسط است؛ و اخر نمره كود كك هـ له و يا بيشتر از هم به دست آمد، كودك داراى اختلال اوتيسم شديد است.

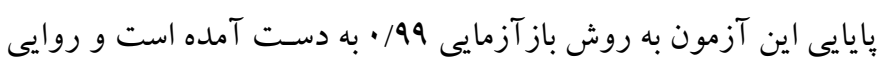

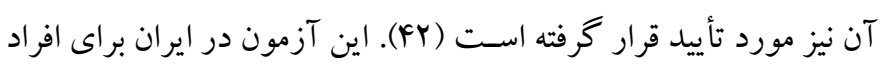

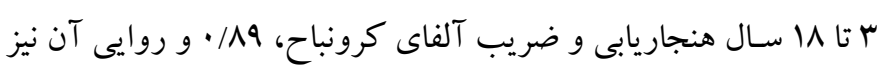

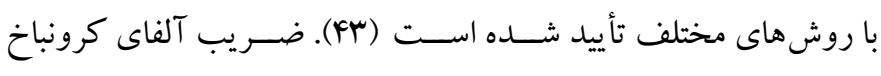

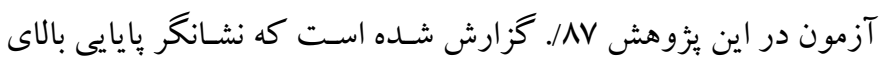

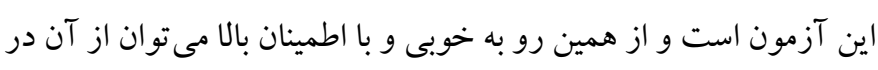
اهداف تشخيصى، بزروهشى، و درمانى استفاده كرد.

1. Gilliam Autism Rating Scale-Second Edition (GARS-2) 
تعريف مى شـود (FF). اين برنامه به صورت Y جلسه در هفته و به مدت Y

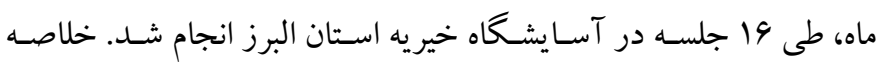

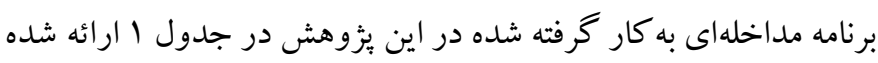

است.
وِاسـخ دادن به يكك محيط، وضعيت و يا كار متفاوت تعريف شده است.

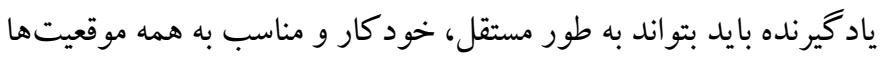

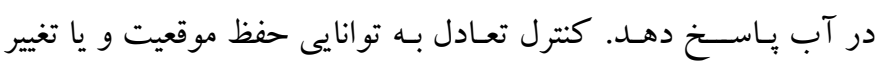

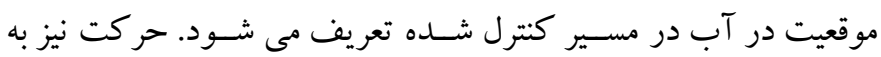

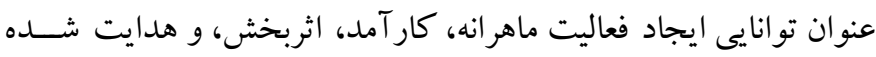

جدول 1: خلاصه برنامه مداخلهاى • ا نقطهاى هالىويكى

\begin{tabular}{|c|c|c|}
\hline ياد گيرى واكنش مناسب به آب، مهار تنفس & تعديل ذهنى & نقطه 1 \\
\hline توانايى مهار حر كات در موقعيت هاى ايستاده & مهار جرخش ساجيتال & تقطه r \\
\hline توانايى مهار حر كات حول محور عرضى بدن & 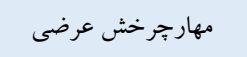 & نقطه r \\
\hline توانيى مهار حر كات در حول محور طولى بدن & 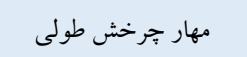 & نقطه F \\
\hline توانايى مهار يكى حركت مانند باز كردن در بطرى & مهارجرخش تر كيبى & نقطه ه \\
\hline درك اين كه آب او راغرق نمى كند & 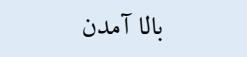 & نقطه 9 \\
\hline حفظ موقعيت پِايدار و آرام بدون حركات حمايتى در دست ها يا ٍاها & ت تعادل در سكون & Vقطه V V V V V \\
\hline مربى فرد را به عقب مى كثد و او بايد حر كات ناخواسته تنه و سر را مهار كند & 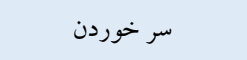 & نقطه 1 \\
\hline انجام يكى حر كت شنا با دست بهصورت مستقل & يشرفت ساده & نقطه 9 \\
\hline حركت دست ها بهصورت قايقرانى & حركت بايه هالى ويكك & نقطه .1. \\
\hline
\end{tabular}

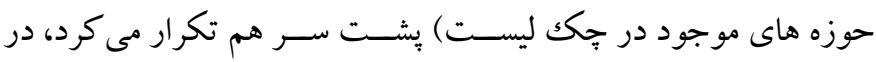

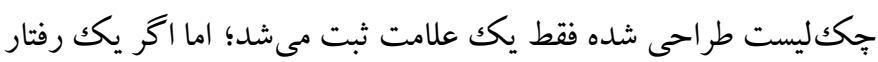

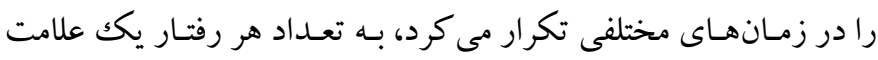

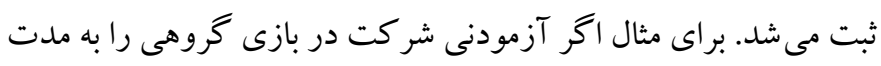

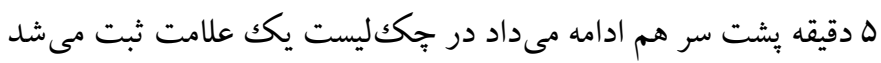
ولى اكر بازى گروهى را با فاصسله هاى زمانى كو تاه (بر ایى مثال هـ دقيقه)

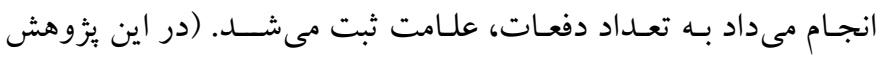

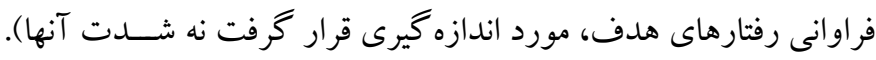

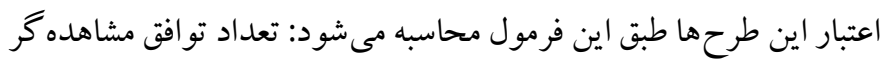

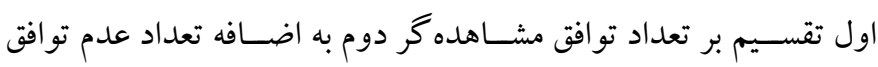
ضرب در صـد. بدين منظور اتاق نخهدارى كود كان داراى دوربين مدار

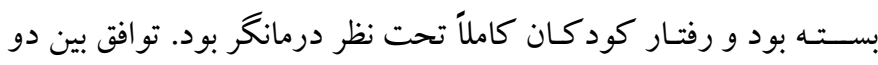

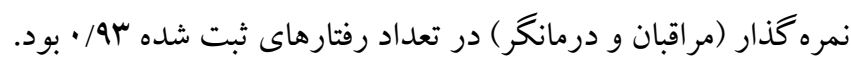

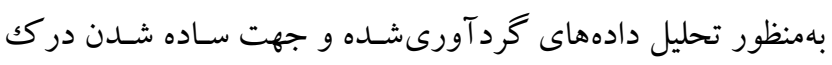

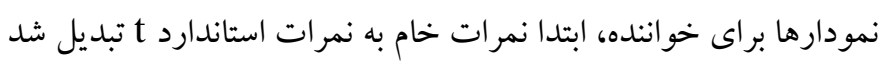

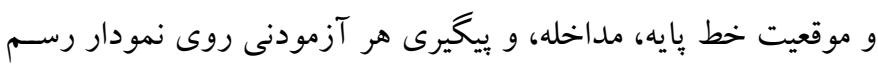

د) روش اجرا: براى تعيين خط پِايه، آزمودنىها در هـ شـبانهروز مورد

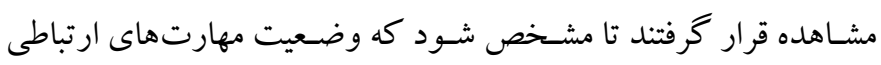

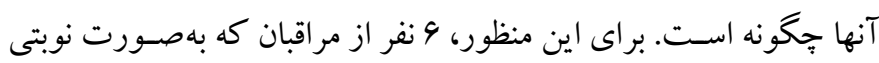

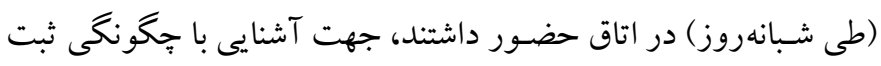
دادهها توسـط روانشـناس مركز آموزش ديدند و سـبس كار تعيين خط

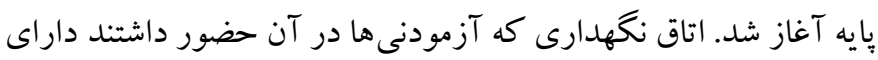

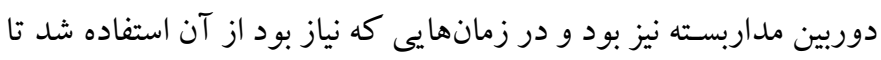

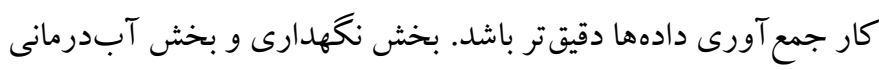

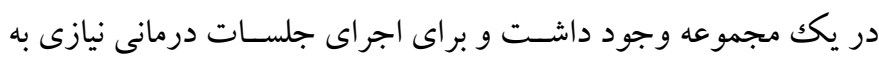

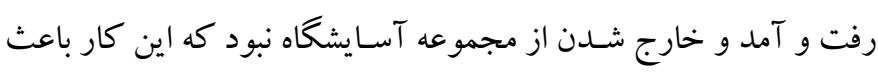

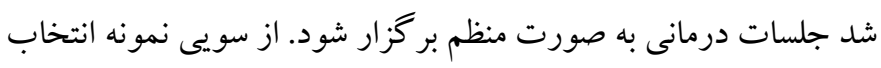

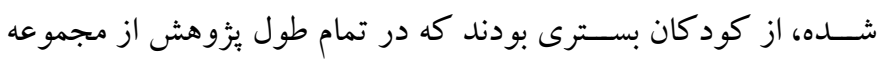

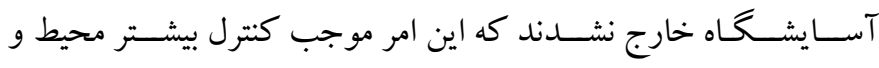

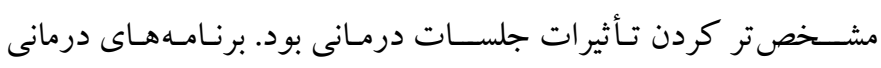

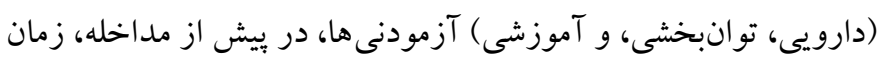

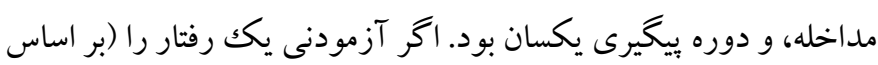




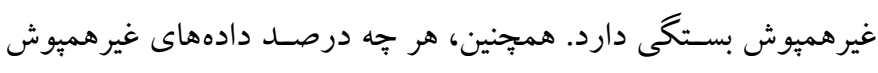
بين دو موقعيت مجاور بالاتر باشـد، با اطمينان بيشـترى مى توان مداخله را اثربخش دانسـت. للزم به ذكر است كه تمامى مر احل تحليل ديدارى اين يزٔوهش، بر اسـاس كتاب طرحهاى مورد منفرد در علوم رفتارى (FD) اقتباس شده است.

\section{يافتهها}

به منظور خلاصـه نمودن نتايج به دسـت آمده، هر يكك از جلسـات خط يايه، مداخله، و بيگيرى براى آزمودنى ها در جداول و نمودارها به شـرح زير گزارش شده است. در جدول ب نمرات تعاملات اجتماعى در موقعيت خط يايه براى هر سه آزمودنى در ينج جلسه خط يايه ارائه شد.

\begin{tabular}{|c|c|c|c|c|c|}
\hline \multicolumn{5}{|c|}{ جلسات خط هايه (A) } & \multirow{2}{*}{ آزمودنى } \\
\hline$\Delta$ & f & $r$ & $r$ & 1 & \\
\hline$\Delta$ & $\Delta$ & $\Delta$ & F & $r$ & آزمودنى 1 \\
\hline F & r & F & F & F & آزمودنى r \\
\hline f & F & F & $\Delta$ & f & آزمودنى \\
\hline
\end{tabular}

در جدول ب نمرات تعاملات اجتماعى در هر يكك از جلسات درمانى و موقعيت بيخيرى ارائه شده است.
شد. سيس جهت تفسير و نتيجه گيرى از اين نمودارها، از تحليل ديدارى، شـاخص روند و شـاخص ثبات، درصـد دادههاى غير هميوش و درصـد دادههاى هميوش استفاده شد. براى تحليل ديدارى نمودار دادهها، يس از رسم نمودار براى هر آزمودنى، در مرحله اول با استفاده از ميانه دادههاى موقعيت خط يايه و مداخله، خط ميانه دادهها موازى با محور X ترسـيم شـــ و يكك محفظه ثبات روى خط ميانه قرار گرفت. محفظه ثبات يعنى مئه دو خط موازى كه يكى بايين و ديخرى بالاى خط ميانه رسـم مىشـود.

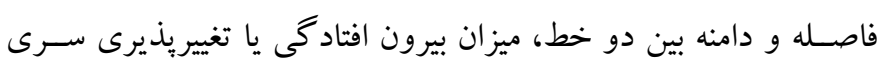

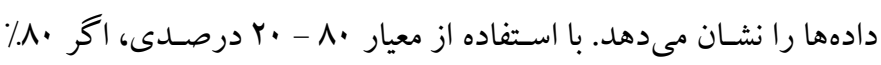
نقاط دادهها زير يا درون ·r درصــد مقدار ميانه (محفظه ثبات) قرار كيرند، گفته مىشـود دادهها ثبات دارند. يّ از آن براى بررسـى روند دادهها، از روش دونيم كردن اسـتفاده شـد و محفظه ثبات خط روند بر

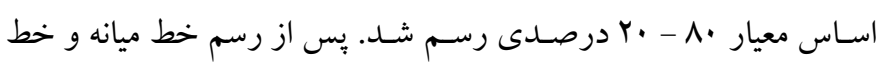
روند و محفظه ثبات آنها، شاخصهاى آمار توصيفى مانند ميانه و ميانگين و شــاخصهاى تحليل ديدارى درونموقعيتى و بينموقعيتى مانند تغيير سطح و روند و درصد دادههاى غيرهميوش محاسبه شد. درصد دادههاى غيرهميوش نشـاندهنده درصــ غيرهميوش نقاط دو موقعيت آزمايشـى (خط يايه و مداخله) اسـت. ميزان كنترل آزمايشـى در يثزوهش مورد منفرد، به تغيير سـطح از يكك موقعيت به موقعيت ديخر و درصد دادههاى

جدول ": نمرات تعاملات اجتماعى در موقعيت مداخله و ييغيرى براى هر سه آزمودنى

\begin{tabular}{|c|c|c|c|c|c|c|c|c|c|c|c|}
\hline \multicolumn{3}{|c|}{ بيغيرى } & \multicolumn{8}{|c|}{ جلسات مداخله (B) } & \multirow{2}{*}{$\frac{\text { آزمودنى }}{-}$} \\
\hline$r$ & r & 1 & $\wedge$ & v & 4 & $\Delta$ & F & r & r & 1 & \\
\hline 11 & 11 & ir & 11 & 11 & 1. & 9 & $\wedge$ & $\wedge$ & $\wedge$ & $\checkmark$ & آزمودنى 1 \\
\hline 11 & ir & ir & ir & ir & 1. & 9 & $\wedge$ & $\wedge$ & V & V & آزمودنى r \\
\hline$\wedge$ & 9 & $\wedge$ & 9 & $\wedge$ & $\wedge$ & $\wedge$ & v & v & $v$ & 4 & آزمودنى r \\
\hline
\end{tabular}

بر اساس جدول ז، مشخص شد كه نمرات تعاملات اجتماعى در هر

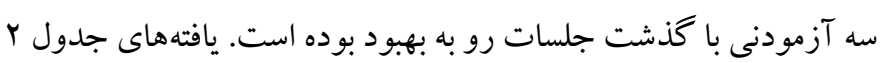
و ب به صورت نمودار دادهها به شرح زير است (نمودار ()). 


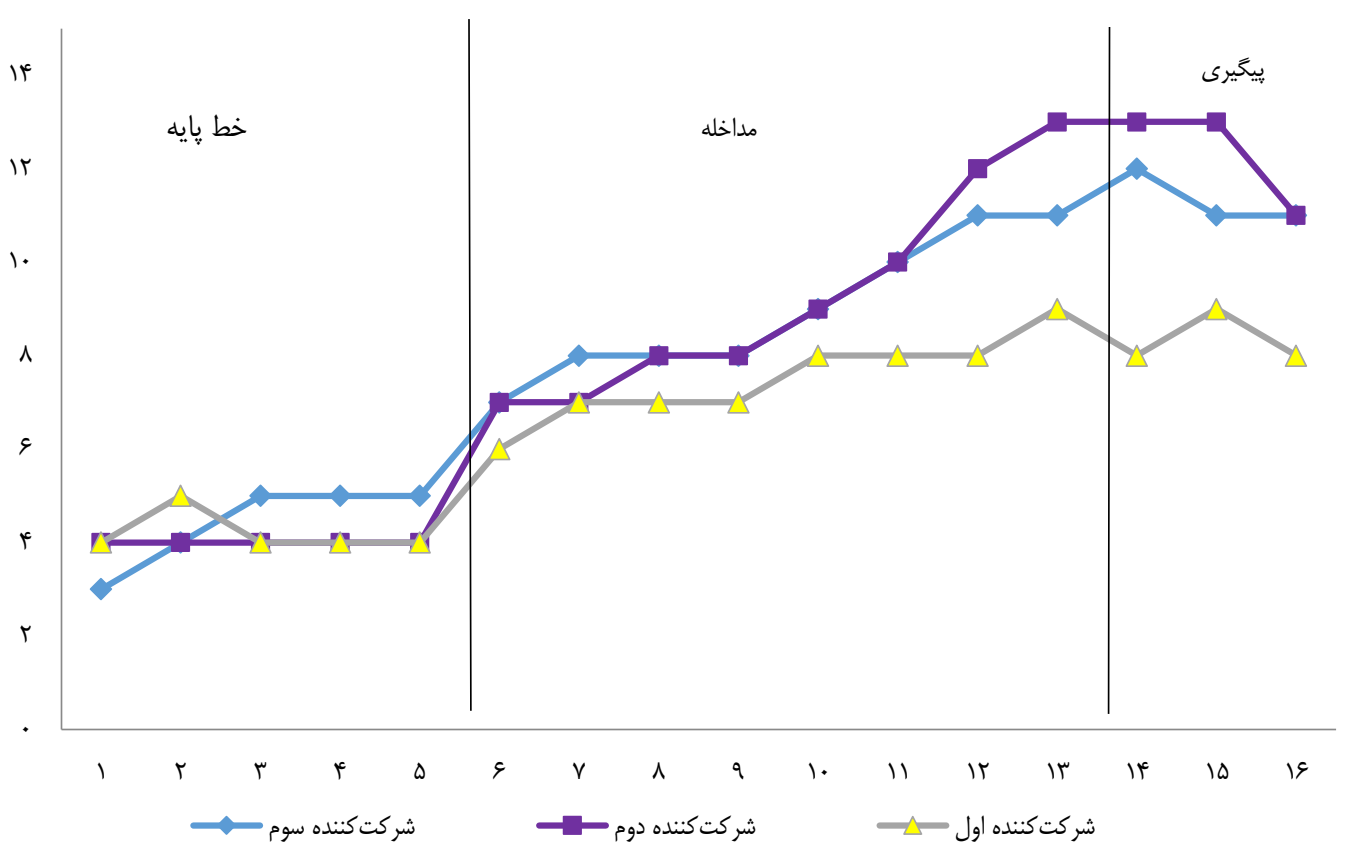

نمودار ا: تغييرات تعاملات اجتماعى براى هر سه آزمودنى

داده شــده اســ، ميانگين تعاملات اجتماعى از F/F در خط پِايه به 9 در

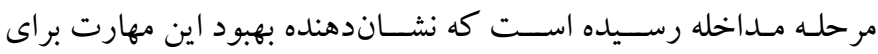

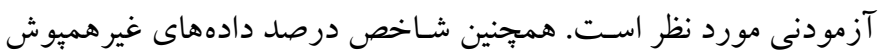
نشـان مى دهد كه ميزان هميوشسى بين نقاط خط بِيه و مداخله با ..1. درصد اطمينان مؤثر بوده است.
نتايج به دسـت آمده براى آزمودنى اول: بر اسـاس تحليل ديدارى

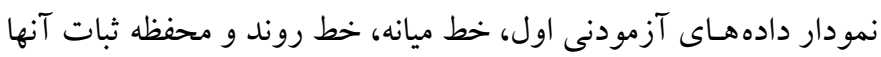
به شـرح زير به دسـت آمده اسـت (نمودار Y). جدول كأ، نتايج تحليل ديدارى درونموقعيتى و بينموقعيتى رابراى نمودار دادههاى آزمودنى ا،

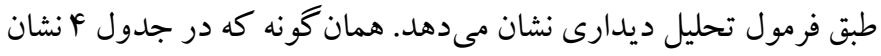

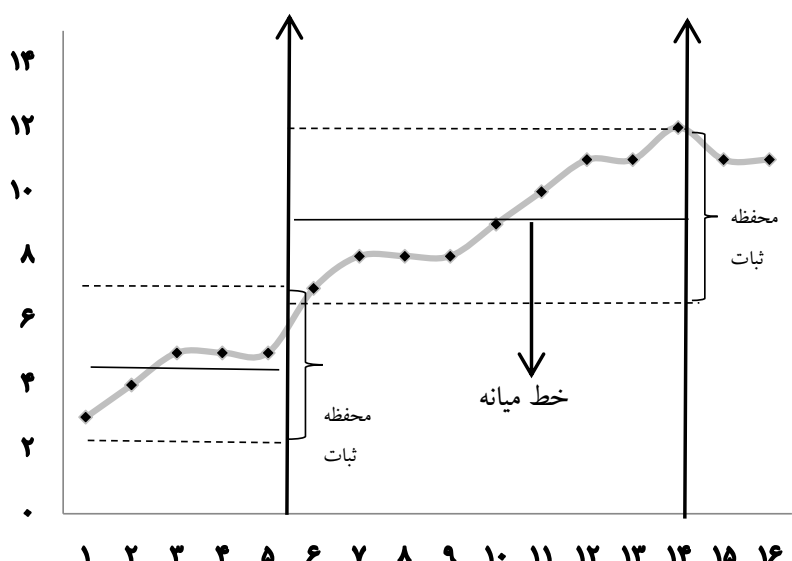

نمودار r: خط ميانه، خط روند و محفظه ثبات آزمودنى اول 
جدول ع: متغيرهاى تحليل ديدارى درونموقعيتى و بينموقعيتى براى آزمودنى اول

\begin{tabular}{|c|c|c|c|c|}
\hline \multicolumn{2}{|c|}{ بين موقعيتى } & \multicolumn{3}{|c|}{ دورن موقعيتى } \\
\hline$A \sqcup$ B & 1. مقايسه موقعيت & B & A & 1. التى موقعيت \\
\hline & 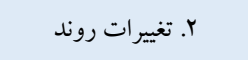 & $\wedge$ & $\Delta$ & 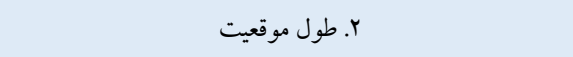 \\
\hline$V_{+}$ & r,l- تغيير جهت & & & 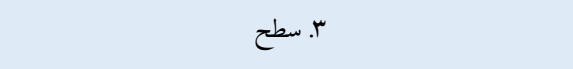 \\
\hline 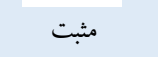 & r r, r اثر وابسته به هدف & $N / \Delta$ & $\Delta$ & 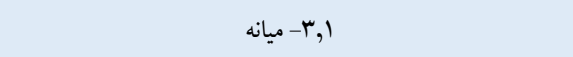 \\
\hline \multirow[t]{2}{*}{ باثبات به باثبات } & 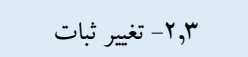 & 9 & $f / F$ & 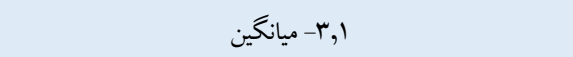 \\
\hline & 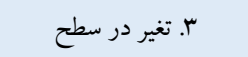 & $11-v$ & $\Delta-r$ & (r,1 \\
\hline$\wedge ه$ & 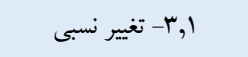 & باثبات & باثبات & l,r-r- دامنه تغييرات محفظه ثبات ·r درصد از ميانه هر موقعيت \\
\hline$V ه$ & 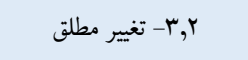 & & & F \\
\hline Nه & 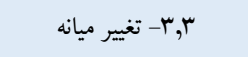 & $11-\wedge$ & $\Delta-F$ & 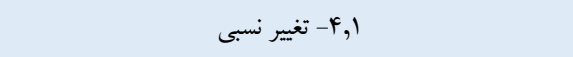 \\
\hline \multirow[t]{2}{*}{94 ب/f } & 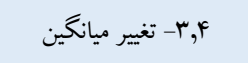 & $11-v$ & $\Delta-r$ & 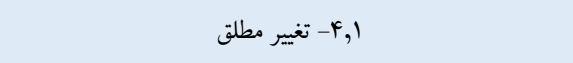 \\
\hline & F أ. هميوشى دادهها & & & هـ هـ روند \\
\hline$\% 1 \ldots$ & PND -r,l & صعودى & صعودى & - - جهت \\
\hline$\%$ & POD -r, & باثبات & باثبات & 1, \\
\hline
\end{tabular}

ه نشان داده شده است، ميانخين استفاده صحيح از سؤ الهاى مختلف در

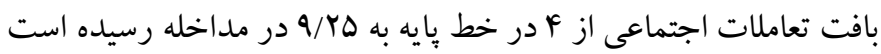

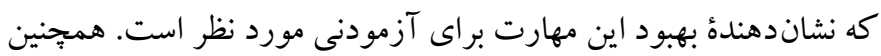

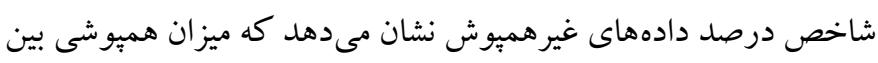
نقاط خط بايه و مداخله با ·1 درصد اطمينان، مؤثر بوده است.
نتايج به دسـت آمده براى آزمودنى دوم: بر اسـاس تحليل ديدارى نمودار دادههاى آزمودنى دوم، خط ميانه، خط روند و محفظه ثبات آنها

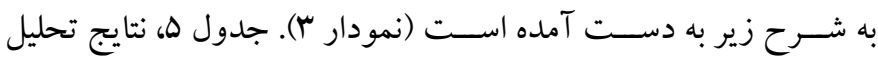
ديـارى درونموقعيتى و بينموقعيتى را براى نمودار دادههـاى آزمودنى نهي

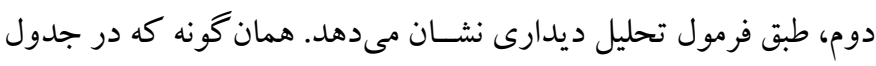
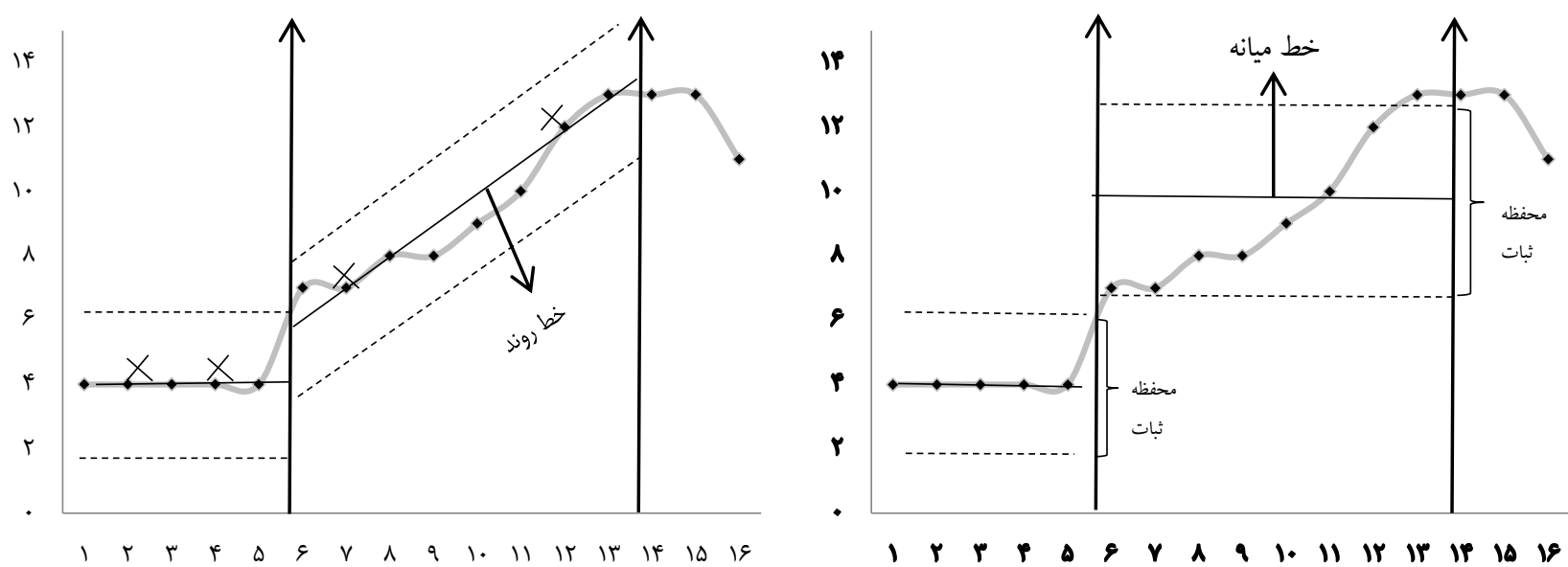

نمودار ஈ: خط ميانه، خط روند و محفظه ثبات آزمودنى دوم 
جدول 0: متغيرهاى تحليل ديدارى درونموقيتى و بينموقعيتى براى آزمودنى دوم

\begin{tabular}{|c|c|c|c|c|}
\hline \multicolumn{2}{|c|}{ بينموقعيتى } & \multicolumn{3}{|c|}{ درونموقعيتى } \\
\hline$A$ B ب B & 1. إيسه موقعيت & B & A & 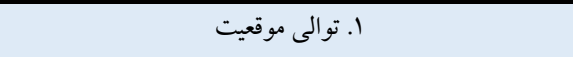 \\
\hline & 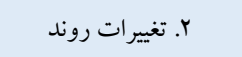 & $\wedge$ & $\Delta$ & 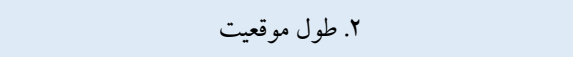 \\
\hline$V_{+}$ & I, I- تغيير جهت & & & 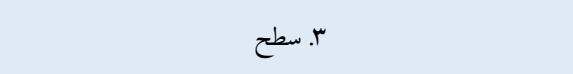 \\
\hline 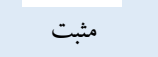 & 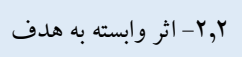 & $F / \Delta$ & r & 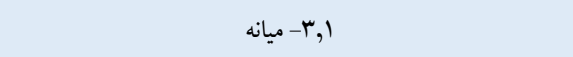 \\
\hline \multirow[t]{2}{*}{ باثبات به باثبات } & 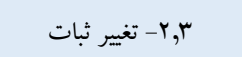 & $9 / r \Delta$ & f & 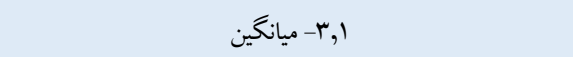 \\
\hline & 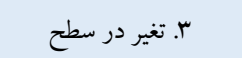 & $i r-v$ & $r-r$ & 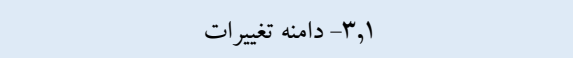 \\
\hline 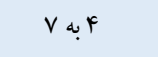 & 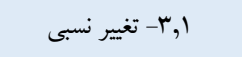 & 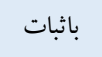 & باثبات & l,r-r- دامنه تغييرات محفظه ثبات ·r درصد از ميانه هر موقعيت \\
\hline V V l & 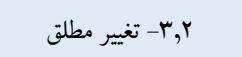 & & & 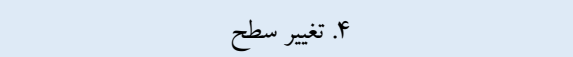 \\
\hline F/ه أبه & 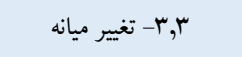 & $I r-V$ & $f-f$ & 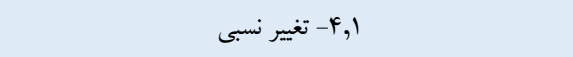 \\
\hline \multirow[t]{2}{*}{ 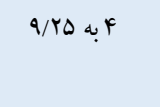 } & 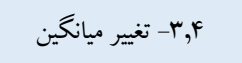 & $1 r-v$ & $r-r$ & 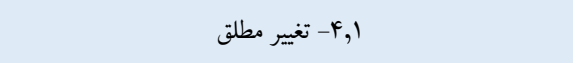 \\
\hline & 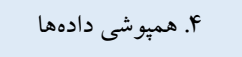 & & & هـ روند \\
\hline$\% 1$. & PND -r,l & صعودى & شيب صفر & - - جهت \\
\hline$\%$. & POD $r, 1$ & باثبات & باثبات & ه-1 ثبات \\
\hline
\end{tabular}

4 نشـان داده شـده اسـت، ميانكين آغاز كرى در سؤال يرسيدن از ب/ در خط بايه به V/D در مداخله رسـيده اسـت كه نشاندهنده بهبود آغاز گرى در سؤال برسيدن براى آزمودنى مورد نظر است. همجينين شاخص درصد دادههاى غيرهمبوش نشـان مى دهد كه ميز ان هميوشى بين نقاط خط يايه و مداخله با •و درصد اطمينان مؤثر بوده است.
نتايج به دسـت آمده براى آزمودنى سـوم: بر اسـاس تحليل ديدارى نمودار دادههاى آزمودنى سوم، خط ميانه، خط روند و محفظه ثبات آنها به شــرح زير به دســت آمده اســت (نمودار F). جدول و، نتايج تحليل ديـدارى درونموقعيتى و بينموقعيتى را براى نمودار دادههـاى آزمودنى سوم، طبق فرمول تحليل ديدارى نشان مىدهد. همان كونه كه در جدول
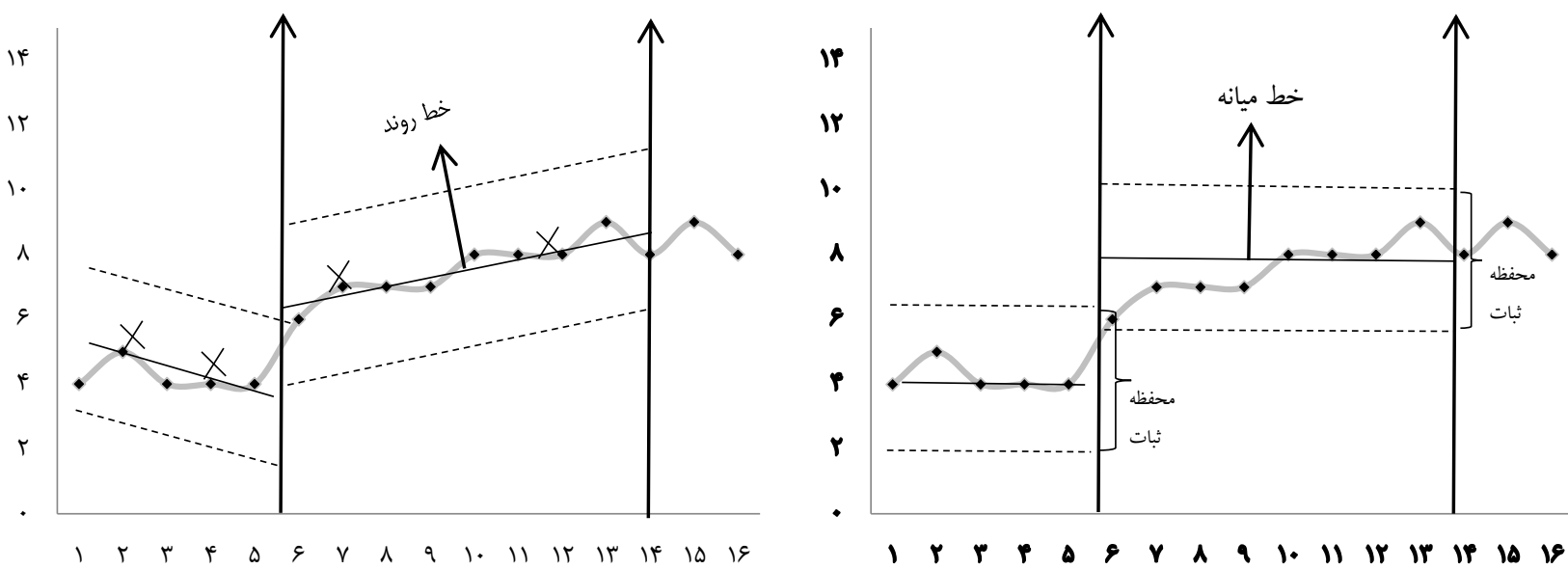

نمودار ع: خط ميانه، خط روند و محفظة ثبات آزمودنى سوم 
جدول 7: متغيرهاى تحليل ديدارى درونموقعيتى و بينموقعيتى براى آزمودنى سوم

\begin{tabular}{|c|c|c|c|c|}
\hline \multicolumn{2}{|c|}{ 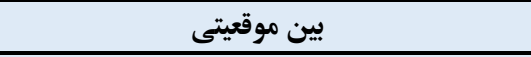 } & \multicolumn{3}{|c|}{ درون موقعيتى } \\
\hline 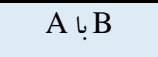 & 1. مقايسه موقعيت & B & A & ا l. الى موقعيت \\
\hline & 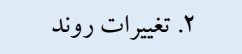 & $\wedge$ & $\Delta$ & 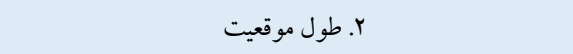 \\
\hline$V_{+}$ & 1, I- تغيير جهت & & & 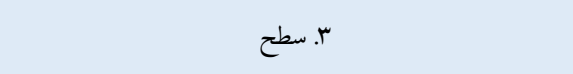 \\
\hline 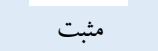 & r,Y- اثر وابسته به هدف & 10 & f & ا \\
\hline \multirow[t]{2}{*}{ باثبات به باثبات } & r r r r r r تغيير ثبات & $V / \Delta$ & $r / r$ & 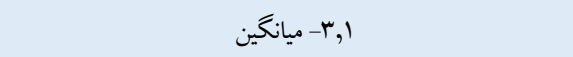 \\
\hline & م. ت تغير در سطح & $9-9$ & $\Delta-\varphi$ & 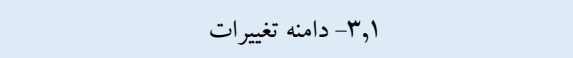 \\
\hline$v ه$ & 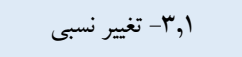 & باثبات & باثبات & ا,r- دامنه تغييرات محفظه ثبات ·r درصد از ميانه هر موقعيت \\
\hline 94 & r r r- ت تغيير مطلق & & & 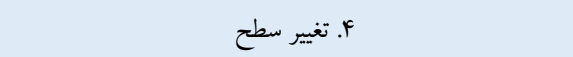 \\
\hline أبه 10 & r,r.r- تغيير ميانه & $\wedge-v$ & $\varphi-\Delta$ & F, F, تغيير نسبى \\
\hline \multirow[t]{2}{*}{$V / \Delta ه / Y$} & 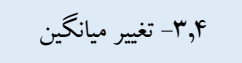 & $9-9$ & $r-r$ & 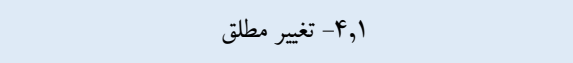 \\
\hline & F. هميوشى دادهها & & & هـ هـ روند \\
\hline$\% 1 \ldots$ & PND - $F, 1$ & صعودى & صعودى & 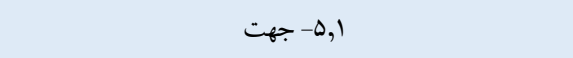 \\
\hline$\%$ & POD - r, & باثبات & باثبات & 0,1 \\
\hline
\end{tabular}

آبدرمانى در افزايش مهارتهاى ارتباطى تأثير داشـته باشـد. شـناورى

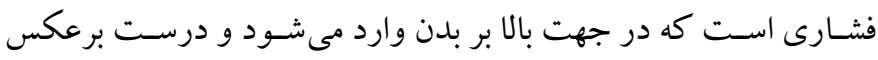

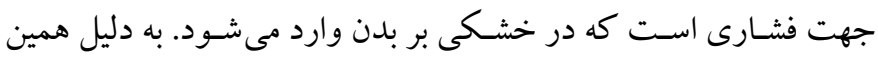

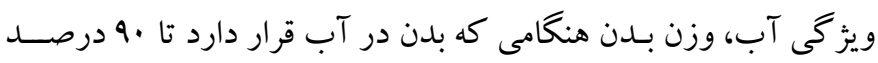

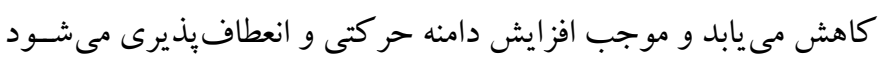

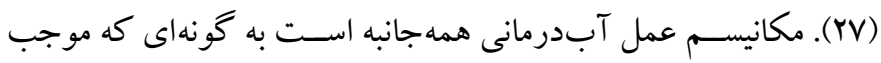

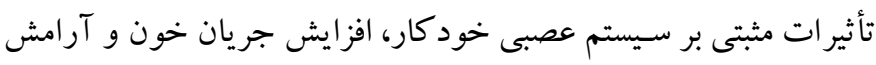

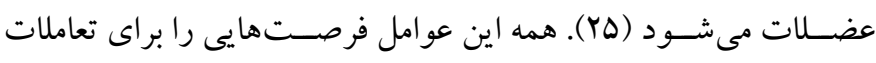

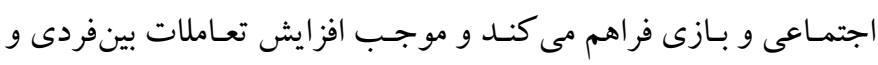

مهارتهاى ارتباطى مىشود (هام).

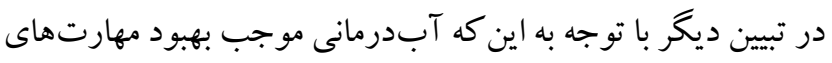

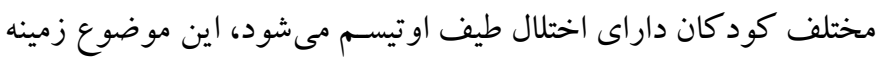

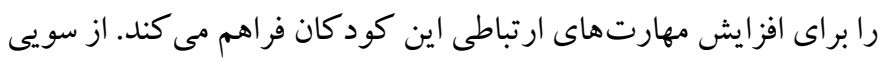

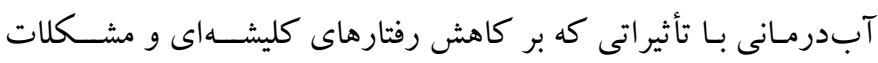

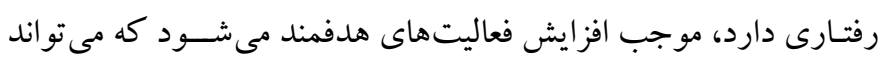

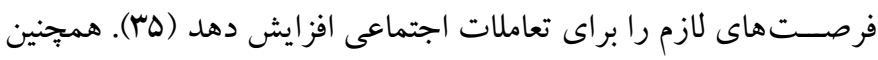

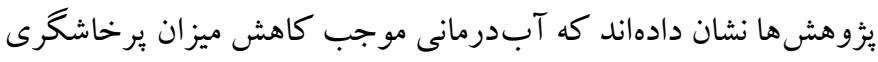

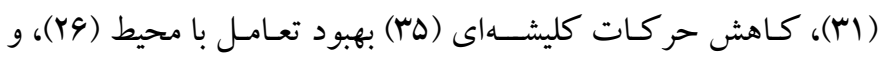

بحث و نتيجه كيرى يُزوهش حاضر با هدف تأثير آبدرمانى بر مهارتهاى ارتباطى كود كان

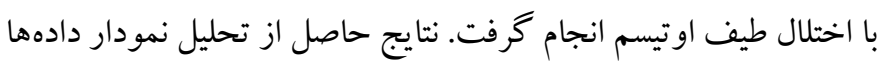

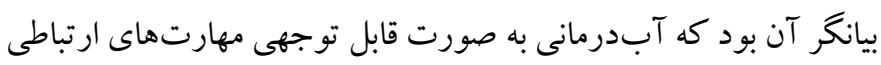

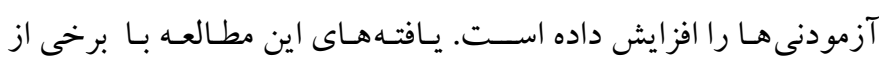

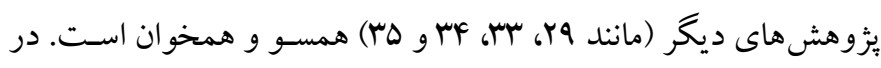

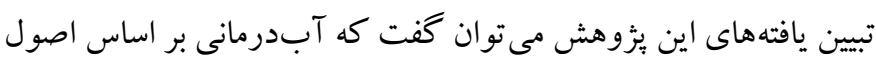

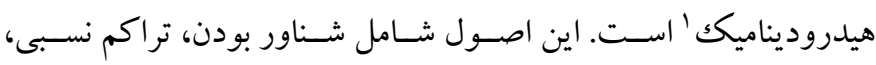
ويسكوزيته، مقاومت، فشـار هيدرواسـتاتيك، تلاطم، و جريان اسـت كه إنه

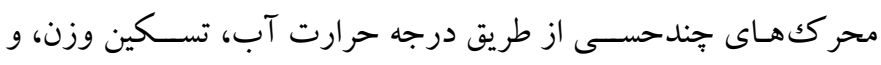

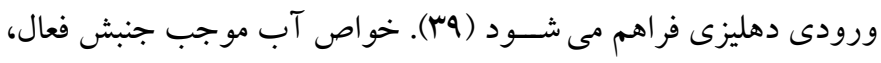

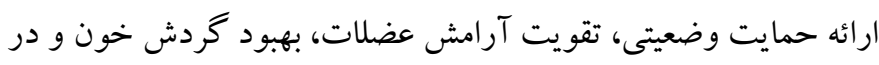
نتيجـه تقويت و تســهيل مهارتهاى حر كتى بر اســاس توانايى هاى فرد

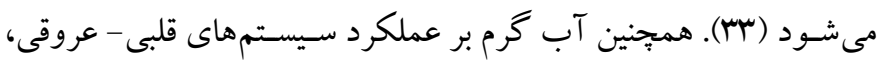

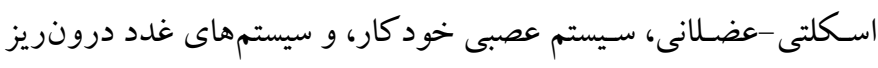

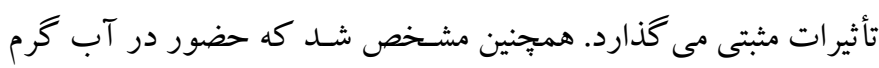

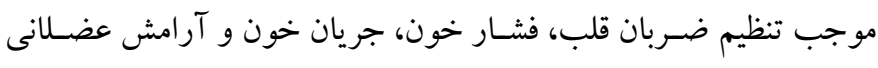
مىشـود ( (F). از جمله فوايد مهم آب، شـناورى است كه باعث مى شود

1. Hydrodynamics 
نسـبت به يزوهش هاى تكك آزمودنى، تعميميذيرى بيشـترى دارند، اما باز

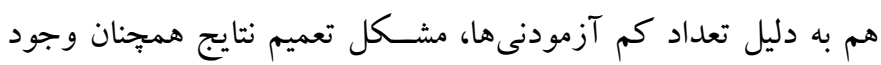

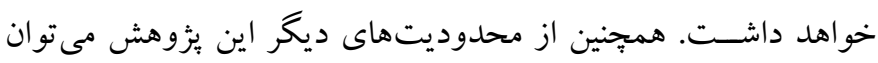

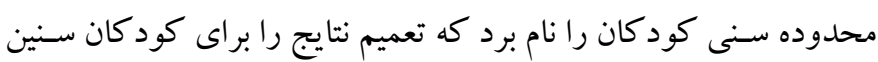

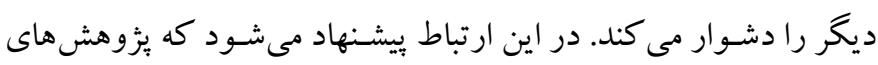

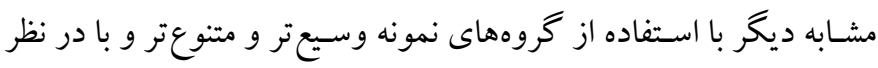

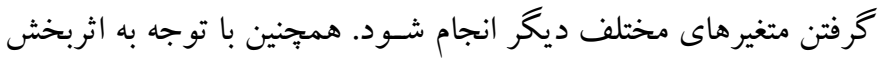

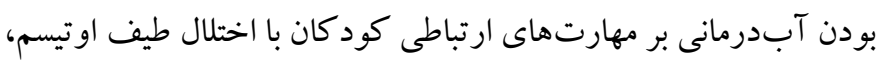

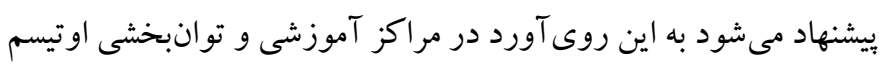
توجه بيشـترى شـود و برنامههاى ويزهاى براى اسـتفاده از اين تمرينها طرحريزى و اجرا شود.

تقدير و تشـكر : اين بيزوهش به صـورت مسـتقل اجرا شـــه اسـت و حاصـل

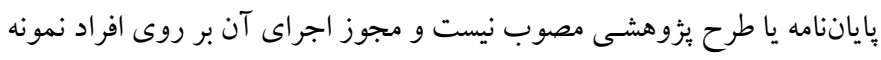

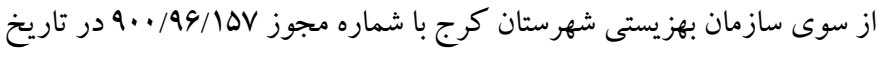

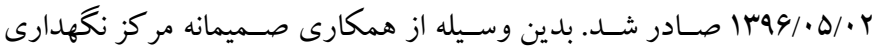

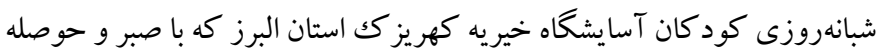

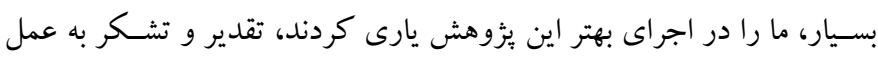
مى آوريم.

تضاد منافع: اين يُووهش براى نويسند كان هيج گونه تضاد منافع نداشته است.
تحريكك سيستم حسى و هيجانى (•F) در كود كان با اختلال طيف اوتيسم

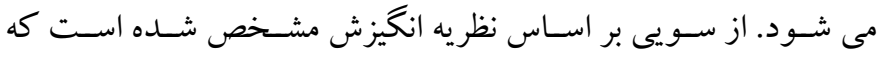

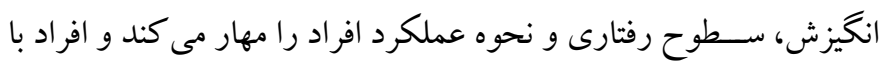

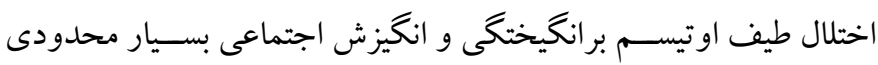

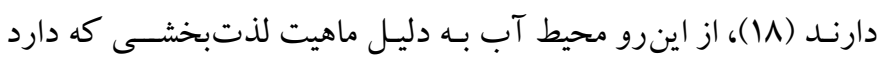

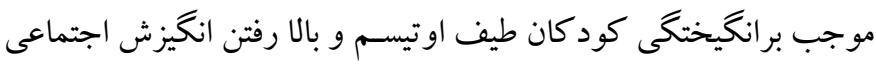

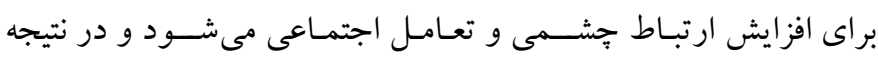
مهارتهاى ارتباطى افزايش مى يابد.

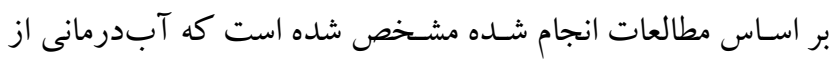

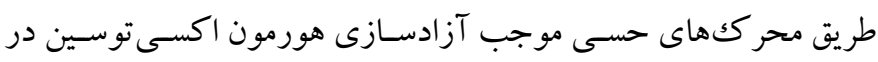

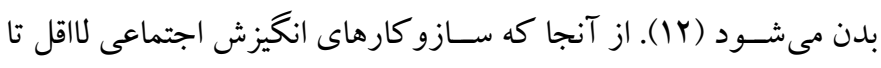

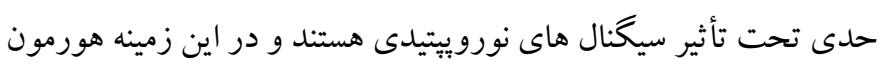

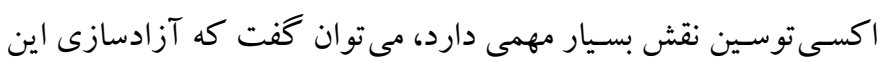

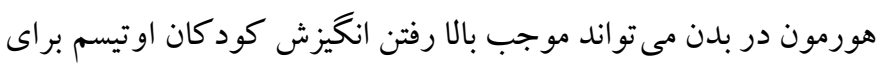

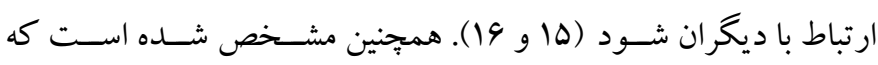

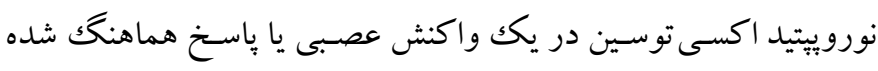

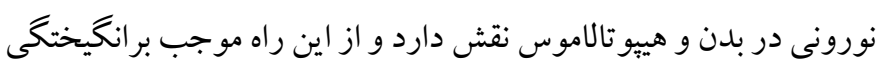

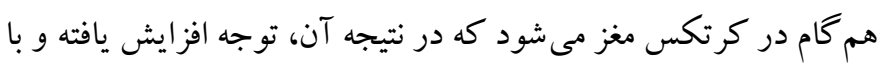
لـذت بخش كردن سـيكنالهـا، حـافظه و ياد گيرى ارتباطى را تقويت

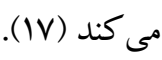

در بايان شـايان ذكر اسـت كه يكى از محدوديتهاى اين يثزوهش تعميميذيرى پايين نتايج آن اسـت. هر جند كه طرحهاى مورد منفرد 


\section{References}

1. American Psychiatric Association. Diagnostic and statistical manual of mental disorders (DSM-5). Washington DC: American Psychiatric Pub; 2013. [Link]

2. Christensen DL, Braun KVN, Baio J, Bilder D, Charles J, Constantino JN, et al. Prevalence and characteristics of autism spectrum disorder among children aged 8 years - autism and developmental disabilities monitoring network, 11 sites, united states, 2012. MMWR Surveill Summ. 2018; 65(13): 1-23. [Link]

3. Zuckerman KE, Mattox K, Donelan K, Batbayar O, Baghaee A, Bethell C. Pediatrician identification of Latino children at risk for autism spectrum disorder. Pediatrics. 2013; 132(3): 445-453. [Link]

4. Kamps DM, Mason R, Heitzman-Powell L. Peer mediation interventions to improve social and communication skills for children and youth with autism spectrum disorders. In: Leaf JB, editor. Handbook of social skills and autism spectrum disorder: assessment, curricula, and intervention. Cham: Springer International Publishing; 2017, pp: 257-283. [Link]

5. Guo X, Duan X, Long Z, Chen H, Wang Y, Zheng J, et al. Decreased amygdala functional connectivity in adolescents with autism: a resting-state fMRI study. Psychiatry Res Neuroimaging. 2016; 257: 47-56. [Link]

6. ten Velden M, Couldrick L, Kinebanian A, Sadlo G. Dutch children's perspectives on the constructs of the child occupational self-assessment (COSA). OTJR (Thorofare N J). 2013; 33(1): 50-58. [Link]

7. Shiri V, Hosseini SA, Pishyareh E, Nejati V, Biglarian A. Study the relationship of executive functions with behavioral symptoms in children with high-functioning autism. Archives of Rehabilitation. 2015; 16(3): 208217. [Persian]. [Link]

8. Parker KJ, Garner JP, Libove RA, Hyde SA, Hornbeak $\mathrm{KB}$, Carson DS, et al. Plasma oxytocin concentrations and OXTR polymorphisms predict social impairments in children with and without autism spectrum disorder. Proc Natl Acad Sci U S A. 2014; 111(33): 1225812263. [Link]

9. Cochran D, Fallon D, Hill M, Frazier JA. The role of oxytocin in psychiatric disorders: A review of biological and therapeutic research findings. Harv Rev Psychiatry. 2013; 21(5): 219-247. [Link]

10. Hollander E, Novotny S, Hanratty M, Yaffe R, DeCaria CM, Aronowitz BR, et al. Oxytocin infusion reduces repetitive behaviors in adults with autistic and
Asperger's disorders. Neuropsychopharmacology. 2003; 28(1): 193-198. [Link]

11. Garrison JL, Macosko EZ, Bernstein S, Pokala N, Albrecht DR, Bargmann CI. Oxytocin/vasopressinrelated peptides have an ancient role in reproductive behavior. Science. 2012; 338(6106): 540-543. [Link]

12. Theofanopoulou C, Boeckx C, Jarvis ED. A hypothesis on a role of oxytocin in the social mechanisms of speech and vocal learning. Proc Biol Sci. 2017; 284(1861): 20170988. [Link]

13. Thye MD, Bednarz HM, Herringshaw AJ, Sartin EB, Kana RK. The impact of atypical sensory processing on social impairments in autism spectrum disorder. Dev Cogn Neurosci. 2018; 29: 151-167. [Link]

14. De Dreu CKW, Kret ME. Oxytocin conditions intergroup relations through upregulated in-group empathy, cooperation, conformity, and defense. Biol Psychiatry. 2016; 79(3): 165-173. [Link]

15. Uvnäs-Moberg K, Handlin L, Petersson M. Selfsoothing behaviors with particular reference to oxytocin release induced by non-noxious sensory stimulation. Front Psychol. 2014; 5: 1529. [Link]

16. Benfield RD, Hortobágyi T, Tanner CJ, Swanson M, Heitkemper MM, Newton ER. The effects of hydrotherapy on anxiety, pain, neuroendocrine responses, and contraction dynamics during labor. Biol Res Nurs. 2010; 12(1): 28-36. [Link]

17. Chevallier C, Kohls G, Troiani V, Brodkin ES, Schultz RT. The social motivation theory of autism. Trends Cogn Sci. 2012; 16(4): 231-239. [Link]

18. Van Etten HM, Carver LJ. Does impaired social motivation drive imitation deficits in children with autism spectrum disorder? Rev J Autism Dev Disord. 2015; 2(3): 310-319. [Link]

19. Bölte S, Marschik PB, Falck-Ytter T, Charman T, Roeyers H, Elsabbagh M. Infants at risk for autism: a European perspective on current status, challenges and opportunities. Eur Child Adolesc Psychiatry. 2013; 22(6): 341-348. [Link]

20. Klein N, Kemper KJ. Integrative approaches to caring for children with autism. Curr Probl Pediatr Adolesc Health Care. 2016; 46(6): 195-201. [Link]

21. Vonder Hulls DS, Walker LK, Powell JM. Clinicians' perceptions of the benefits of aquatic therapy for young children with autism: a preliminary study. Phys Occup Ther Pediatr. 2006; 26(1-2): 13-22. [Link]

22. Yilmaz İ, Konukman F, Birkan B, Yanardağ M. Effects of most to least prompting on teaching simple progression swimming skill for children with autism. Educ Train Autism Dev Disabil. 2010; 45(3): 440-448. [Link] 
23. Fleming SA, Gutknecht NC. Naturopathy and the primary care practice. Prim Care. 2010; 37(1): 119136. [Link]

24. Yadav R, Karmakar N, Satapathy T, Roy A. An evidence-based new insight into treatment of diseases by hydrotherapy. Int J Pharm Sci Res. 2019; 10(1): 5769. [Link]

25. Dumas H, Francesconi S. Aquatic therapy in pediatrics: annotated bibliography. Phys Occup Ther Pediatr. 2001; 20(4): 63-78. [Link]

26. Mooventhan A, Nivethitha L. Scientific evidencebased effects of hydrotherapy on various systems of the body. N Am J Med Sci. 2014; 6(5): 199-209. [Link]

27. Felcar JM, Probst VS, de Carvalho DR, Merli MF, Mesquita R, Vidotto LS, et al. Effects of exercise training in water and on land in patients with COPD: a randomised clinical trial. Physiotherapy. 2018; 104(4): 408-416. [Link]

28. Uvnas-Moberg K, Petersson M. Oxytocin, a mediator of anti-stress, well-being, social interaction, growth and healing. Z Psychosom Med Psychother. 2005; 51(1): 57-80. [Link]

29. Yanardag M, Akmanoglu N, Yilmaz I. The effectiveness of video prompting on teaching aquatic play skills for children with autism. Disabil Rehabil. 2013; 35(1): 47-56. [Link]

30. Shams-Elden M. Effect of aquatic exercises approach (halliwick-therapy) on motor skills for children with autism spectrum disorders. Ovidius University Annals, Series Physical Education \& Sport/Science, Movement \& Health. 2017; 17(2): 490-496. [Link]

31. Arjmandnia AA, Azimigarosi S, Mohseni Ezhei A, Javadi Asayesh S. Effectiveness of hydrotherapy on the degree of aggression in children with autism spectrum disorder: a single-subject study. The Scientific Journal of Rehabilitation Medicine. 2018; 7(4): 249-260. [Persian]. [Link]

32. Oriel KN, Kanupka JW, DeLong KS, Noel K. The impact of aquatic exercise on sleep behaviors in children with autism spectrum disorder: a pilot study. Focus Autism Other Dev Disabl. 2016; 31(4): 254-261. [Link]

33. Battaglia G, Agrò G, Cataldo P, Palma A, Alesi M. Influence of a specific aquatic program on social and gross motor skills in adolescents with autism spectrum disorders: three case reports. Journal of Functional Morphology and Kinesiology. 2019; 4(2): 27. [Link]

34. Bumin G, Uyanik M, Yilmaz I, Kayihan H, Topçu M. Hydrotherapy for Rett syndrome. J Rehabil Med. 2003; 35(1): 44-45. [Link]
35. Mortimer R, Privopoulos M, Kumar S. The effectiveness of hydrotherapy in the treatment of social and behavioral aspects of children with autism spectrum disorders: a systematic review. J Multidiscip Healthc. 2014; 7: 93-104. [Link]

36. Lee J, Porretta DL. Enhancing the motor skills of children with autism spectrum disorders: a pool-based approach. Journal of Physical Education, Recreation \& Dance. 2013; 84(1): 41-45. [Link]

37. Chu C-H, Pan C-Y. The effect of peer- and siblingassisted aquatic program on interaction behaviors and aquatic skills of children with autism spectrum disorders and their peers/siblings. Res Autism Spectr Disord. 2012; 6(3): 1211-1223. [Link]

38. Rosa R, Molisso V. Integrated motor activities and autism spectrum disorder: biodanza srt and multisystem water therapy (Mwt). Giornale Italiano di Educazione alla Salute, Sport e Didattica Inclusiva. 2018; 4(2): 40-48. [Link]

39. Caputo G, Ippolito G, Mazzotta M, Sentenza L, Muzio MR, Salzano S, et al. Effectiveness of a multisystem aquatic therapy for children with autism spectrum disorders. J Autism Dev Disord. 2018; 48(6): 19451956. [Link]

40. Pan C-Y. Effects of water exercise swimming program on aquatic skills and social behaviors in children with autism spectrum disorders. Autism. 2010; 14(1): 9-28. [Link]

41. Petrofsky J, Baxter J, Bomgaars J, Burgert C, Jacobs $S$, Lyden D, et al. The influence of warm hydrotherapy on the cardiovascular system and muscle relaxation. [California, United States]: Department of Physical Therapy, Loma Linda University; 2003, pp: 1-39. [Link]

42. Montgomery JM, Newton B, Smith C. Test review: Gilliam, J. (2006). GARS-2: Gilliam autism rating scale-second edition. Austin, TX: PRO-ED. J Psychoeduc Assess. 2008; 26(4): 395-401. [Link]

43. Ahmadi S j, Safari T, Hemmatian M, Khalili Z. The psychometric properties of Gilliam autism rating scale (GARS). Research in Cognitive and Behavioral Sciences. 2011; 1(1): 87-104. [Persian]. [Link]

44. Grosse SJ. The Halliwick method: water freedom for individuals with disabilities. West Wabash Avenue, Milwaukee: Aquatic Consulting and Education Resource Services; 2001. [Link]

45. Ledford JR, Gast DL. Single subject research methodology in behavioral sciences: applications in special education and behavioral sciences. 1st Edition. New York: Routledge; 2009, pp: 87-95. [Link] 
36. Werthamer-Larsson L, Kellam S, Wheeler L. Effect of first-grade classroom environment on shy behavior, aggressive behavior, and concentration problems. Am J Community Psychol. 1991; 19(4): 585-602. [Link]

37. Goossens FA, Olthof T, Dekker PH. New participant role scales: comparison between various criteria for assigning roles and indications for their validity. Aggress Behav. 2006; 32(4): 343-357. [Link]

38. Espelage DL, Holt MK. Bullying and victimization during early adolescence: peer influences and psychosocial correlates. Journal of Emotional Abuse. 2001; 2(2-3): 123-142. [Link]

39. ChalmehR. Psychometrics properties of the ilinois bullying scale (IBS) in Iranian students: validity, reliability and factor structure. Journal of
Psychological Models and Methods. 2014; 3(11): 3952. [Persian]. [Link]

40. Cernkovich SA, Giordano PC. School bonding, race and delinquency.Criminology. 1992; 30(2): 261-291. [Link]

41. Alberto P, Troutman AC. Applied behavior analysis for teachers. (8th ed.). Upper Saddle River, NJ: Pearson; 2009, pp: 1-480. [Link]

42. Parsonson BS. Evidence-based classroom behavior management strategies. Kairaranga. 2012; 13(1): 1623. [Link]

43. Caravita SCS, Blasio PD, Salmivalli C. Unique and interactive effects of empathy and social status on involvement in bullying. Soc Dev. 2009; 18(1): 140163. [Link] 